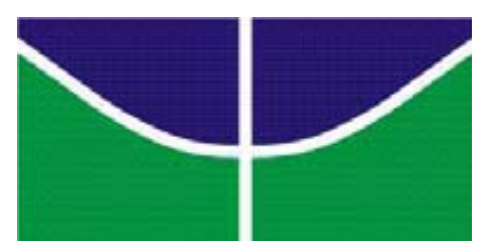

UNIVERSIDADE DE BRASÍLIA

INSTITUTO DE RELAÇÕES INTERNACIONAIS

CURSO DE ESPECIALIZAÇÃO

EM RELAÇÕES INTERNACIONAIS

Aluna: Priscila Larissa Arraes Mendes

ANÁLISE COMPARATIVA ENTRE AS

AGENDAS EXTERNAS DO BRASIL E DA VENEZUELA

Monografia de conclusão do XI Curso

de Especialização em Relações Internacionais para a Universidade de Brasília, apresentada como requisito parcial para a obtenção do título de Especialista em Relações Internacionais.

Brasília, 
PRISCILA LARISSA ARRAES MENDES

\title{
ANÁLISE COMPARATIVA ENTRE AS AGENDAS EXTERNAS DO BRASIL E DA VENEZUELA: TEMAS INTERNACIONAIS MAIS DESTACADOS
}

\begin{abstract}
Monografia de conclusão do XI Curso de Especialização em Relações Internacionais para a Universidade de Brasília, apresentada como requisito parcial para a obtenção do título de Especialista em Relações Internacionais.
\end{abstract}

Orientador:

Prof. Dr. Alcides Costa Vaz

Brasília, 


\section{FICHA CATALOGRÁFICA}

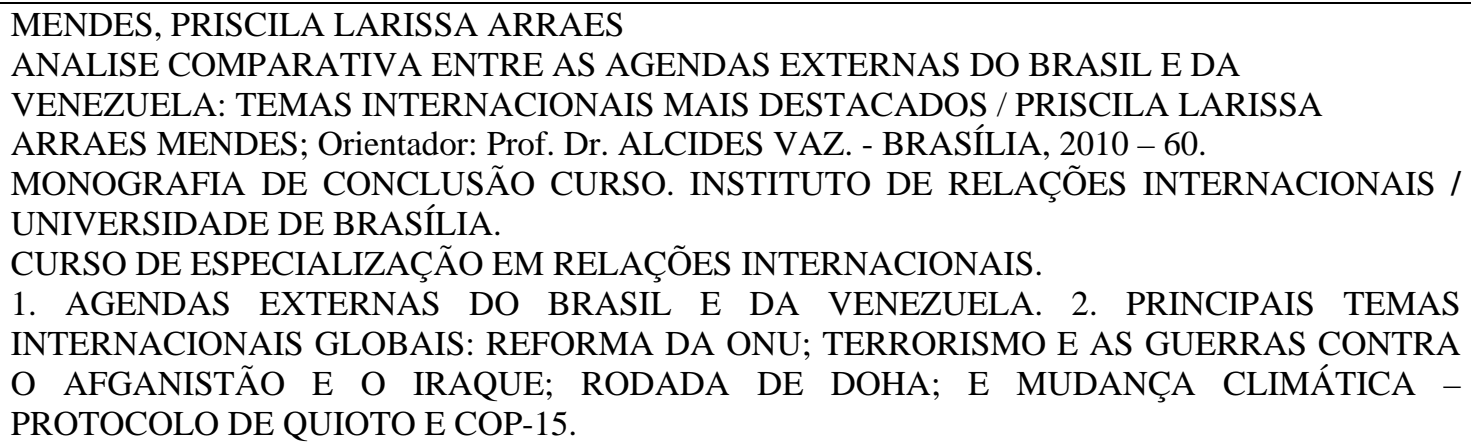


Aos meus pais Euvaldo e Meire, pelo apóio constante. 


\section{AGRADECIMENTOS}

A Deus, por estar comigo em todos os momentos.

Aos meus pais Euvaldo e Meire, pelo incentivo.

Aos meus sócios e amigos Pablo e Rafaela e à minha amiga Alexandra, pelo apoio e paciência.

Ao meu orientador Prof. Dr. Alcides Costa Vaz, pelo direcionamento e ajuda.

À Embaixada da República Bolivariana da Venezuela, em especial ao funcionário do setor cultural, Wilfredo Machado, pelas informações prestadas.

Aos meus amigos venezuelanos Adriana e Edgard pelas informações e materiais prestados.

Aos colegas e amigos do curso de Especialização em Relações Internacionais pelos bons momentos de aula e diversão que tivemos.

Finalmente, à equipe de professores e funcionários do Instituto de Relações Internacionais da UnB, pelas aulas e colaboração. 


\section{RESUMO}

As agendas externas do Brasil e da Venezuela aparentam certa semelhança em razão da proximidade entre os mandatários Lula e Chávez. Sob essa motivação, procurou-se comparar as agendas de ambos os governos para descobrir seu grau de proximidade. Analisou-se, ao longo do texto, se a reforma da ONU; as ações dos EUA no combate ao terrorismo, no Afeganistão e no Iraque; a rodada de Doha da OMC; e a mudança climática, em especial, o Protocolo de Quioto e a COP-15 são ou não temas importantes para a Venezuela e o Brasil e se o posicionamento e atitudes perante os assuntos coincidem.

Palavras chaves: agenda externa, Lula, Chávez, Conselho de Segurança da ONU, terrorismo, Rodada de Doha e mudança climática. 


\begin{abstract}
The Brazilian and Venezuelan international agendas appear to share some similarity due to proximity between presidents Lula and Chavez. Because of this motivation, the present work shall compare the external agendas of both governments to determine the degree of proximity. This paper discuss whether or not foreign policy and if the position and attitudes towards the following subjects are similar: UN reform, U.S. actions in combating terrorism in Afghanistan and Iraq, the Doha round of negotiations of WTO and climate change, in particularly the Kyoto Protocol and COP-15.
\end{abstract}

Key words: external agenda, Lula, Chavez, Security Council UN, terrorism, the Doha Round and climate change. 


\section{GLOSSÁRIO}

ADMs - Armas de Destruição em Massa;

API - Instituto Americano de Petróleo;

ASA - Cúpula América do Sul - África;

CMC - Convenção de Mudanças Climáticas;

CNUMAD - Conferência das Nações Unidas para o Meio Ambiente;

COP-15 - 15ª Cúpula sobre Mudança Climática da ONU, em Copenhague;

CS - Conselho de Segurança;

EUA - Estados Unidos Americanos;

FARC - Armadas Revolucionárias da Colômbia;

FHC - Fernando Henrique Cardoso;

FMI - Fundo Monetário Internacional;

G-4 - Grupo dos 4;

G-20 - Grupo dos 20;

G-77/China - Grupo dos 77 mais China;

GATS - General Agreement on Trade in Services;

GATT - General Agreement on Tariffs and Trade;

IPCC - Painel Intergovernamental sobre Mudança Climática;

IRA - Exército Revolucionário Irlandês;

MCTII - Ministério del Poder Popular para la Ciencia y Tecnología;

MDL - Mecanismo de Desenvolvimento Limpo;

MENPET - Ministério del Poder Popular para la Energia y Petróleo;

MF - Ministério del Poder Popular para las Finanzas;

MINAMB - Ministério del Poder Popular para el Ambiente;

MRE - Ministério das Relações Exteriores;

NAMA - Mercados para os Produtos Não-agrícolas;

PAC - Política Agrícola Comum;

OEA - Organização dos Estados Americanos;

OMC - Organização Mundial de Comércio;

ONU - Organização das Nações Unidas;

OPEP - Organização dos Países Exportadores de Petróleo; 
TIAR - Tratado Interamericano de Assistência Recíproca;

TLC - Tratado de Livre Comércio;

TPRB - Órgão de Exame das Políticas Comerciais;

TPRM - Trade Policy Review Mechanism;

TRIPs - Trade-related Aspects of Intellectual Property Rights; e UE - União Europeia. 


\section{SUMÁRIO}

\section{Glossário}

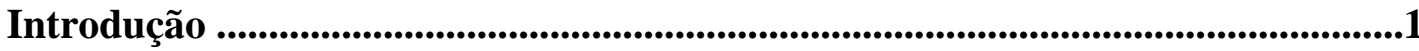

I. Temas destacados da agenda internacional em âmbito global .......................... 3

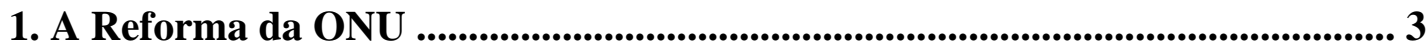

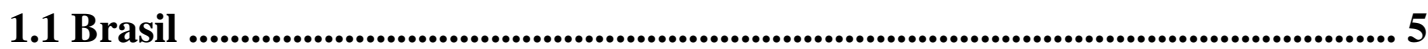

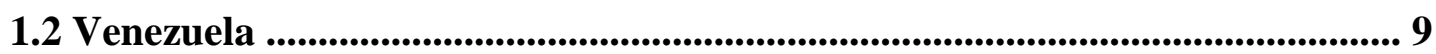

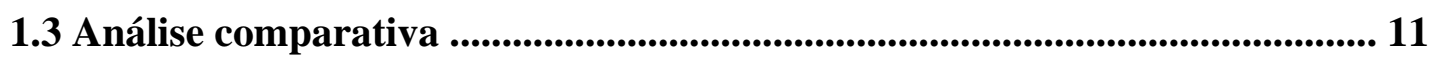

2. Ações dos EUA no combate ao terrorismo, no Afeganistão e no Iraque ....... 13

2.1 Brasil ........................................................................................................................ 18

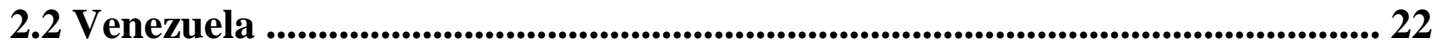

2.3 Análise comparativa .................................................................................................... 25

3 Rodada Doha da OMC ................................................................................. 27

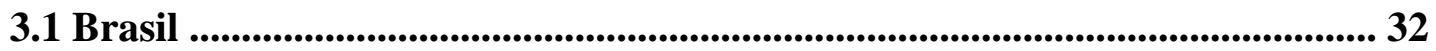

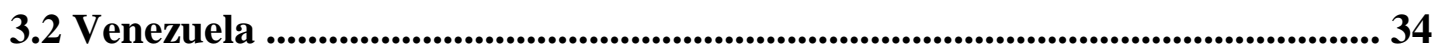

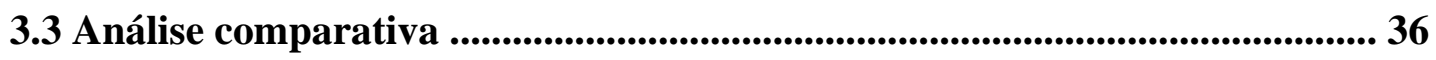

4 Mudança Climática: Protocolo de Quioto e COP-15 ............................................ 38

4.1 Brasil ............................................................................................................................................ 43

4.2 Venezuela .......................................................................................................................... 48

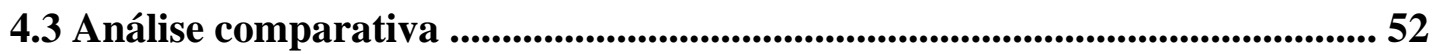

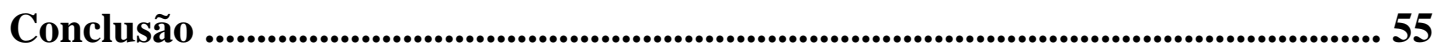

Bibliografia ........................................................................................................... 57 


\section{INTRODUÇÃO}

Houve no começo do mandato de Luis Inácio Lula da Silva, em 2003, inclusive desde a campanha eleitoral - tendência de comparar suas atitudes e políticas às do governo de Hugo Chávez Frias, em razão das origens de oposição esquerdista e da amizade entre eles. Temia-se que Lula seguisse os passos de seu colega, na condução das políticas internas e externas. Esse temor, noticiado pela mídia, provinha principalmente das elites dos dois países e das nações desenvolvidas, em especial, dos Estados Unidos.

O próprio presidente Lula afirmou, em entrevista realizada em Copenhague, no final do ano passado, que não havia qualquer rivalidade com o presidente Hugo Chávez, e sim, diferença de estilos. De fato, confirmou que tem excelente relação pessoal e institucional com Chávez, e, como resultado disso, os países nunca viveram um momento tão positivo no campo diplomático.

Tanto o Brasil quanto a Venezuela praticam a diplomacia presidencial e viajam com comitivas numerosas em suas reuniões pelo mundo. As declarações emitidas por ambos os presidentes são destacadas no noticiário, direcionando os olhares para seus respectivos Estados na cena internacional. Eles participam ou emitem comunicado nos principais foros. Portanto, chama a atenção o modo de condução de suas agendas externas.

A intenção deste trabalho é comparar as agendas, com destaque para os principais temas internacionais. O projeto inicial era trabalhar com os assuntos mais importantes no âmbito global, continental e regional. Mas, pela complexidade das temáticas globais, não foi possível estender o trabalho para os demais campos, porque extrapolaria o limite permitido desta monografia, relegando os restantes para futuros trabalhos acadêmicos.

Os temas escolhidos para analisar as políticas exteriores do governo Chávez e Lula foram a reforma da ONU; as ações dos EUA no combate ao terrorismo, no Afeganistão e no Iraque; a rodada Doha da OMC; e a mudança climática, em especial, o Protocolo de Quioto e a COP - 15. Esses tópicos foram preferidos, haja 
vista a projeção dos mesmos no mundo, pois afetam indistintamente todos os países do globo e porque vigoram desde a origem do mandato de ambos ${ }^{1}$ até a atualidade.

O objetivo geral é comparar as agendas externas de ambos os governos. O objetivo específico é detectar, ao longo da explanação, se os respectivos tópicos são ou não assunto predominante nas agendas da Venezuela e do Brasil e se o posicionamento e atitudes perante os assuntos coincidem. A hipótese com que se trabalha é que o Lula age de forma diferente de Chávez, a agenda externa brasileira ainda é direcionada principalmente pelo corpo diplomático, e a da Venezuela é conduzida pelo Chefe de Estado.

Os capítulos que dividem esta monografia foram nomeados pelos temas. Antes de especificar a política dos Países, é feita uma contextualização destacando os pontos principais do debate. Cada capítulo foi subdividido em subtítulos que destacam o posicionamento do Brasil, da Venezuela e da analise comparativa de ambos. Para a feitura deste trabalho utilizou-se de pesquisa documental em livros, artigos científicos, entrevistas e discursos das autoridades, conversas e notícias dos principais periódicos e páginas de internet - a maioria de comunicação oficial, de onde se extraíram o embasamento das análises comparativas.

\footnotetext{
${ }^{1}$ A origem de alguns assuntos antecedeu à posse dos líderes.
} 


\section{TEMAS DESTACADOS DA AGENDA INTERNACIONAL EM ÂMBITO GLOBAL}

\section{A Reforma da ONU}

A reforma da Organização das Nações Unidas (ONU) é um assunto das relações internacionais que voltou a ter importância pouco antes do sexagésimo aniversário - celebrado em 2005. A ONU é uma instituição com o objetivo basilar de preservar a segurança e a paz mundial, cujo principal garante é o Conselho de Segurança (CS). Mas, desde sua criação até a atualidade, as ameaças mundiais transmutaram, destacando-se os ataques terroristas de 11 de setembro de 2001, o que implicou na necessidade de reforçar as ações multilaterais. O contexto atual demanda modificações na natureza do tratamento das questões de paz e segurança, por meio de maior institucionalização e estruturas que conectem desenvolvimento a segurança, sustentado no conceito de segurança humana ${ }^{2}{ }^{3}$

Afirma MELLO (2005, p.15) que “cada vez mais, um dos desafios da ONU é prever conflitos, atacando as causas profundas da instabilidade e da violência política, tais como a pobreza, a falta de educação e as disparidades e desigualdades entre povos e comunidades”. Essa autora destaca ainda a existência de 3 dimensõeschave da segurança coletiva: a primeira salienta que a ameaça contra um Estado é uma ameaça contra todos, porquanto não obedece às fronteiras das nações; a segunda faz referência a que todo Estado depende da cooperação internacional para sua segurança; e a terceira é que nem todos os Estados têm a capacidade ou vontade política de responder por sua responsabilidade de proteger a própria população ou de não causar dano ao vizinho. ${ }^{4}$

Caso a ONU não seja capaz de alçar-se para enfrentar as novas ameaças, afundar-se-ia em meio à discórdia entre Estados membros e ações unilaterais ${ }^{5}$. Deve modernizar-se para enfrentar, segundo MELLO (2005, p. 19) 6 categorias de intimidações: "guerra entre Estados; violência entre Estados, incluindo as guerras

\footnotetext{
${ }^{2}$ Segundo MELLO (2005, p.7), o conceito de segurança humana enfoca o indivíduo e não os Estados, justifica-se pelo fato de que a maioria dos conflitos atuais são internos, inclusive, muitas vezes, o próprio Estado praticam a violência sobre sua população.

${ }^{3}$ MELLO, V.C., Novas ameaças a paz e segurança: o papel da ONU. Reformas na ONU. 2005. Cap.

1 , p. 7 e 17.

${ }^{4}$ Idem, p. 18

${ }^{5}$ Idem.
} 
civis, violações de direitos humanos em larga escala e genocídio; pobreza, doenças infecciosas e destruição do meio ambiente; armas nucleares, químicas, biológicas e radiológicas; terrorismo; crime organizado transnacional.”. O então Secretário Geral Kofi Annan solicitou, em 2003, um estudo sobre quais seriam os novos flagelos da humanidade para o século XXI e qual seria o papel da ONU diante deles, cujo relatório debater-se-ia entre os Estados - membros ${ }^{6}$.

Atualmente, o Conselho de Segurança está conformado da seguinte maneira, desde a única reforma sofrida em 1961: 15 Estados, dos quais 5 dispõem de assento permanente com poder de veto (EUA, Rússia, China, França e Grã-Bretanha) e 10 têm mandato de 2 anos, sem poder de veto, cuja distribuição é por critério geopolítico: 5 para África e Ásia; 2 para América Latina e Caribe; 1 para a Europa oriental e 2 para a Europa ocidental. Justifica-se à ampliação do CS, em razão da restrita composição atual, do aumento dos membros da ONU e da emergência de Estados que se equiparam aos membros permanentes, de modo econômico, militar e culturalmente ${ }^{7}$.

A proposta atual de reforma do CS é aumentar o Conselho de 15 para 24 membros, para tanto foram apresentados 2 propostas:

1. Novos membros seriam permanentes sem direito a veto; e

2. Membros semi-permanentes que devem ser eleitos pelo Conselho a cada 4 anos, e podem ser re-eleitos.

Nenhuma das opções prevê o direito de veto, uma vez que o consenso parece ser de que o veto deve ser erradicado, ao invés de ser atribuído aos novos integrantes. A proposta, igualmente, anunciava a revitalização da Assembléia Geral e do ECOSOC e o revigoramento da Comissão de Direitos Humanos ${ }^{8}$ - que já foi realizada.

Apesar de se ter estudo que justifique a necessidade da reforma e comprova a proliferação de atores internacionais e a complexidade do novo sistema de interação mundial, ainda não se chegou a uma definição. Continua-se na fase de negociações,

\footnotetext{
${ }^{6}$ Idem.

${ }^{7}$ ARRAES, V. O Brasil e a ONU, 1999 a nossos dias: das grandes conferências às grandes pretensões. Relações Internacionais do Brasil: Temas e Agendas. Orgs. ALTEMANI, H. e LESSA, A.C. 2006. Volume 2, Cap. 1 p. 7-41.

${ }^{8}$ MELLO, V.C., Novas ameaças a paz e segurança: o papel da ONU. Reformas na ONU. 2005. Cap. 1 , p. 22 e 23.
} 
devido, principalmente, a falta de interesse dos membros permanentes em promovêla.

\subsection{Brasil}

A reforma da ONU é um ponto importante para Política Externa do Governo Lula, consagrada no discurso de posse do Presidente, em 01/01/2003: "Defenderemos um Conselho de Segurança reformado, representativo da realidade contemporânea com países desenvolvidos e em desenvolvimento das várias regiões do mundo entre os seus membros permanentes” (Lula, 2003).

Desde a existência do Conselho Executivo da Liga das Nações, o Brasil destacaria sua vontade de compor o órgão de instância decisória maior para projetar seu prestígio nacional ${ }^{9}$. Comenta ARRAES (2006, p.) que inclusive o Brasil teve o apoio do presidente Franklin Roosevelt em decorrência de sua geografia continental, população e potencial de desenvolvimento.

Conforme esse autor, desde o governo de Fernando Henrique Cardoso (FHC), a pretensão brasileira como membro permanente do Conselho de Segurança da ONU significaria uma tentativa de modificar a imagem do Brasil, de cunho depreciativo em relação à questão Amazônica, direitos humanos e escândalos políticos da Presidência da República. A obtenção dessa vaga significaria, também, reconhecimento do Estado pela sociedade internacional e legitimaria o corolário do projeto de reforma interno brasileiro: estabilização monetária e a modificação do perfil do Estado, ao integrar mais o País à economia internacional, além de significar a atração de mais prestígio externo. ${ }^{10}$

Essa é uma aspiração que nas últimas duas décadas foi destacada em diferentes momentos: nos aniversários de 50 e 60 anos da ONU (1995 e 2005); e durante as pronunciações sobre o ataque de 11 de setembro ${ }^{11}$. Inclusive, alguns anos antes, o presidente José Sarney proporia o alargamento do CS, durante a reunião da Assembléia-Geral, em 1989. No início dos anos 1990, o País apontou como credenciais para o mérito sua postura democrática, pacifista, legalista e multilateral,

${ }^{9}$ ARRAES, V. O Brasil e a ONU, 1999 a nossos dias: das grandes conferências às grandes pretensões. Relações Internacionais do Brasil: Temas e Agendas. Orgs. ALTEMANI, H. e LESSA, A.C. 2006. Volume 2, Cap. 1 p. 7-41.

${ }^{10}$ Idem, p. 26.

${ }^{11}$ Idem, p. 27. 
apesar de sua deficiência na área militar; além disso, aspiraria como representante regional dos países periféricos ${ }^{12}$. Durante o período presidencial de Itamar Franco manteve-se a idéia de alargamento do CS, porém sem direito a veto, pelo menos no início ${ }^{13}$.

Durante a presidência de Cardoso a aspiração brasileira foi ondulante, ora prioridade ora não. O governo de FHC, por meio do Min. Luiz Felipe Lampreia, solicitou ao Secretário Geral da ONU Boutros Boutros Ghali 5 vagas permanentes sem direito a veto, sendo uma para o Brasil. Advertiria, porém, FHC que não era uma reivindicação do país, mas sim forma de democratizar a ONU. O então Secretário Geral sugeriu a participação do país em mais operações de paz, a fim de asseverar a justeza da pretensão brasileira. ${ }^{14}$

A trajetória de reivindicação do assento brasileiro no CS por Luis Inácio Lula da Silva remonta momentos antes a sua posse como presidente da República. Em 2002, Lula, em viagem aos EUA, aludiu a reforma do CS com a contemplação de cadeiras permanentes para Latino América e África, a fim de democratizar o órgão. ${ }^{15}$ Segundo ARRAES (2005, p. 37), a política externa do governo Lula persegue com obstinação a vaga fixa no Conselho de Segurança, ao representar um desejo de recomposição internacional.

Ao reiterar a pretensão, a política externa dedicar-se-ia a angariar apoio da comunidade internacional: conquistou a aprovação sul-americana da Venezuela, Peru, Bolívia e Chile; africana de Angola e África do Sul; européia de Portugal, França, Rússia, Grã-Bretanha e Alemanha; e asiática de China, Índia e Japão, dentre outros. Ainda, em visita do representante cingapurense, em novembro de 2008, o Brasil confirmou o apoio dessa nação ${ }^{16}$. O Embaixador José Viegas, ex-Ministro da

\footnotetext{
12 Ponto contestado pelo México e pela Argentina. Idem, p. 28.

13 Idem, p. 28.

${ }^{14}$ Idem, p. 29-36

${ }^{15}$ Idem, p. 36.

${ }^{16}$ Discurso do Presidente da República, Luiz Inácio Lula da Silva, durante almoço em homenagem ao Primeiro-Ministro da República de Cingapura, Lee Hsien Loong, Brasília, DF, 25/11/2008.

Disponível em: http://www.mre.gov.br/portugues/politica_esterna/discurso/discurso_detalhe3.asp?ID_DISCURSO=3 404. Acesso em: 08/02/2008.
} 
Defesa, foi encarregado de percorrer a América do Sul em busca de sustentação oficial ao pleito. $^{17}$

O Brasil mantém diversos argumentos e estratégias para promover sua candidatura ao assento. Uma delas foi o aproveitamento da importância atribuída pelos EUA ao Conselho de Segurança antes da Segunda Guerra do Golfo, em 2003, momento em que aproveitou para destacar a convivência harmoniosa e estável do continente americano. Outra estratégia foi compor a missão de paz no Haiti, em fevereiro de 2004, em consonância com o conselho dado pelo ex-Secretário da ONU Boutros Boutros Ghali de participar em mais missões de paz. Em novembro do mesmo ano, formou com Alemanha, Japão e Índia - países interessados na ampliação dos membros do CS e aspirantes à vaga - o grupo dos $4(\mathrm{G}-4)^{18}$.

Com relação às 2 propostas de reforma, o Brasil apóia a que sugere a ampliação de membros permanentes ${ }^{19}$, tal proposta seria a opção do Embaixador brasileiro Baena Soares - que foi um dos membros do Painel de Alto Nível das Nações Unidas sobre Ameaças, Desafios e Mudanças-, quem sugere os seguintes nomes: Brasil, Índia, Japão, Alemanha, África do Sul e Egito. A primeira alternativa disponibilizaria seis novos assentos de caráter permanente e mais três rotativos com mandato estipulado em dois anos, de sorte que a divisão geográfica compor-se-ia, sem considerar previamente os 5 com veto, assim: África (2 fixos mais 4 renováveis); Américas (1 mais 4); Ásia e Pacífico (2 mais 3); e Europa (1 mais 2) ${ }^{20}$.

Um dos critérios para se eleger um candidato é a contribuição à manutenção da paz. Com relação a isso, o Brasil defende que contribui bastante para a paz e a segurança internacional, porquanto o faz desde os anos 50 e, a partir daí, tem participado em 25 operações de paz, mediante o envio de tropas e observadores militares, policiais e eleitorais. Algumas das missões foram: no Oriente Médio, em 1956; na África - Angola, Moçambique, África do Sul, Libéria e Uganda -; América

\footnotetext{
${ }^{17}$ ARRAES, V. O Brasil e a ONU, 1999 a nossos dias: das grandes conferências às grandes pretensões. Relações Internacionais do Brasil: Temas e Agendas. Orgs. ALTEMANI, H. e LESSA, A.C. 2006. Volume 2, Cap. 1 p. 39.

${ }^{18}$ Idem, p. 38.

${ }^{19}$ VALLE, V.M., A reforma do Conselho de Segurança da ONU: uma análise sobre a posição brasileira e suas repercussões. Reformas na ONU. Cap. 4, p. 103-104, ano 2005.

${ }^{20}$ ARRAES, V. (2006) op. cit. Ref. 17; p. 39.
} 
Latina - El Salvador, Nicarágua e Guatemala -; Europa - Chipre, Croácia, Macedônia e Bósnia-Herzegovina -; e Ásia - Camboja e Timor Leste ${ }^{21}$.

Destaca VALLE (2005, p. 104) a contribuição brasileira para a paz internacional por meio da promoção da prevenção dos conflitos em que se devem atender temas como pobreza; desigualdade e padrões insustentáveis de desenvolvimento. Nesse sentido, o presidente Lula implementou o programa Fome Zero internamente, e liderou, junto com outros, a Cúpula contra a Pobreza e a Fome - na 59a sessão da Assembléia Geral em 2004. Atualmente seu labor de destaque é a realizada no Haiti, junto a Missão das Nações Unidas para a Estabilização no Haiti (MINUSTAH). Além disso, pode-se dizer que o Brasil contribui para a paz e a segurança mundiais, porque não se envolve em conflitos armados nem utiliza a energia atômica para fins não pacíficos.

Há ainda os pontos argumentativos sobre o número de habitantes; a importância econômica; a disposição de contribuir para as atividades econômicas e políticas, as operações de manutenção da paz e de apoio; e as contribuições financeiras para a ONU, incluídas os fundos e programas voluntários. Com relação à primeira, o Brasil conta atualmente com mais de 194 milhões ${ }^{22}$ de habitantes. Sobre o segundo ponto pode-se dizer que o PIB brasileiro é de US\$ 1.375 trilhão, estando entre os 10 maiores e seu território é de $8.511 .965 \mathrm{Km}^{2}$, além disso, é um país rico em recursos naturais. A respeito dos pontos quarto e quinto, o País contribui ativamente para as atividades econômicas e políticas, foi membro fundador da ONU e participa da maioria das agências especializadas, apesar de não ser grande contribuinte financeiro da ONU, sendo esta outra debilidade de sua candidatura, além do quesito militar ${ }^{23}$.

O Brasil também ingressaria, junto com a Nigéria e a Índia, para integrar o grupo dos países em desenvolvimento, que se postulam diante do argumento de que esses tipos de países estejam representados adequadamente ${ }^{24}$. Segundo ARRAES (2006, p. 39), “o país observaria como indispensável a ampliação do arco decisor, de sorte que seria impreterível a reforma, por meio do alargamento, do CS. A extensão

\footnotetext{
${ }^{21}$ VALLE, V.M., A reforma do Conselho de Segurança da ONU: uma análise sobre a posição brasileira e suas repercussões. Reformas na ONU. 2005. Cap. 4, p. 103-104.

${ }^{22}$ Almanaque Abril 2009, Ed. Abril, p. 410, ano 2009.

${ }^{23}$ VALLE, V.M. (2005), op. cit. Ref. 21; p. 104-108.

${ }^{24}$ Idem, p. 105.
} 
conciliar não deveria, portanto, ratificar a distância entre desenvolvidos e subdesenvolvidos, com a incorporação de mais países do Norte, porém abranger, finalmente, o Sul por meio da influência de critérios geopolíticos”.

\subsection{Venezuela}

O debate diplomático na Venezuela afirma que o CS se apresenta como o maior obstáculo para as ações direcionadas à segurança humana, porquanto suas resoluções se sujeitam ao antigo conceito de segurança de Estado - cada vez menos compatível com a atualidade. Destaca que o envio de tropa ao Haiti e ao Líbano; as sanções contra o Irã; as propostas antidemocráticas e pouco representativas da estrutura do CS exemplificam a urgência da reforma de conteúdo conceitual, a fim de adaptá-lo à complexa realidade internacional atual. ${ }^{25}$

O centro de altos estudos diplomático venezuelano Pedro Gual defende a bandeira de que o conceito de segurança Estadual está ultrapassado e, em substituição a este, deveria aplicar-se o de segurança humana - elaborado pelo PNUD-, congruente com o atual sistema internacional. Considera, para isso, necessário modificar os padrões que limitam a atuação de órgãos, como o Conselho de Segurança, a conceitos de segurança nos moldes tradicionais. ${ }^{26}$

O posicionamento do país é de apoio a reforma do CS. Essa reforma é cônsona com a defendida pelos países em desenvolvimento e a do Painel de Alto Nível da ONU, haja vista a necessidade da adoção de medidas para enfrentar os problemas que impedem o desenvolvimento dos países, que por sua vez intensificam outros dele derivados. Inclusive, o presidente Chávez, apresentou uma proposta no $50^{\circ}$ aniversário da ONU, propondo 4 pontos, na reunião da Assembleia Geral e reiterou-as no ano seguinte; foram elas:

1. A ampliação do CS, tanto dos membros permanentes quanto os rotativos, contando com novos países desenvolvidos e em desenvolvimento;

2. A melhoria dos métodos de trabalho adotado, de forma a aumentar a transparência, o respeito e a inclusão;

\footnotetext{
${ }^{25}$ Boletín do Instituto de Altos Estudios Diplomáticos Pedro Gual. Asuntos Globales N. 8. Artigo: En búsqueda de un nuevo concepto de seguridad: la seguridad humana vs. el Consejo de Seguridad. Ano 2007. Disponível em: www.institutopedrogual.edu.ve. Acesso em: 09/03/2010.

${ }^{26}$ Idem.
} 
3. A supressão do poder de veto - pedido reiterado há 6 anos -, considerado elitista e contrário a democracia; e

4. O fortalecimento do papel do Secretário Geral, especialmente, em suas funções políticas no âmbito da diplomacia preventiva, a qual deve ser consolidada.

Afirma o presidente que a gravidade dos problemas convoca transformações profundas, e que simples reformas não são suficientes para obstar os problemas mundiais e por isso, mais do que reformar o CS da ONU, seria necessário a reinaugurar da organização internacional. ${ }^{27}$

A chancelaria venezuelana afirma que o País é ator de significativa importância na propositura do novo modelo de Segurança e da reestruturação do sistema das Nações Unidas. Aponta que a política interna de "Segurança Integral” do governo venezuelano pode servir como sustentáculo na construção do novo modelo, aplicável as decisões do CS. A "Segurança Integral” fundamenta-se no desenvolvimento integral; no gozo e exercício de direitos e garantias nos campos econômicos, sociais, políticos, culturais, geográficos, ambientais e militares; e valores constitucionais voltados ao povo e às instituições que formam o Estado. ${ }^{28}$

Segundo VALENTE, L. e SANTORO, M. a Venezuela não procura, contudo, desenvolver estratégia para obtenção de liderança regional ou mundial, via a integração do CS. Afirmam eles que mesmo sendo um País estratégico do ponto de vista energético, não possui estrutura social, poder político e atributos geográficos que a permitam exercer liderança, nem mesmo diante o Brasil, Argentina ou México. E acrescentam que ainda que o presidente Chávez idealizasse um País mais ativo no cenário internacional, com voz e maior autonomia, isso não necessariamente significa ter pretensões de liderança. Não é do interesse da Venezuela tentar ingressar no Conselho de Segurança da ONU como membro permanente porque seria inútil, independentemente de quem estivesse no poder ou dos recursos utilizados para esse fim.

\footnotetext{
${ }^{27}$ Discurso do presidente da Venezuela Hugo Chávez na Sexagésima Assembleia Geral das Nações Unidas. Ano 2005. Disponível em: http://es.wikisource.org/wiki/Discurso_del_Presidente_Hugo_Ch\%C3\%A1vez_en_la_Asamblea_Gen eral_de_la_ONU_de_2005. Acesso em: 10/03/2010.

${ }^{28}$ Idem.
} 
Desde o governo de Caldeira, segundo VIZENTINI, P. (200, p.), a Venezuela apoiava o ingresso do Brasil no CS ampliado. Frisava o então governo que "esperava modificações como a ampliação da representação permanente, dando-lhe um posto seguro ao Brasil no CS.”, igualmente, “a América Latina tem direito a esta posição pela sua fortaleza espiritual e sua atitude constante em prol da liberdade e amizade entre os povos.”.

A Venezuela, segundo a Ata do Recife de 2003, reconhece a necessidade de fortalecimento do ambiente multilateral de cooperação no âmbito da ONU, com a afirmação da necessidade de reforma do Conselho de Segurança e apóia expressamente à aspiração brasileira de um assento como membro permanente desse $\operatorname{organismo}^{29}$. Mais recentemente, consta no Plano Nacional Simon Bolívar (2007, p. 49), como projeto de política internacional, avançar em ações decididas na transformação da ONU, junto com diversos movimentos internacionais que propugnam essa iniciativa.

\subsection{Análise comparativa}

A reforma da ONU, em especial do Conselho de Segurança, é tema que apresenta importância diferenciada nas agendas externas brasileira e venezuelana. Inclusive, o comportamento dos dois difere entre si. Ambos os países, entretanto, argumentam a carência de inovações e a importância da adaptação da ONU ao atual cenário internacional.

O Brasil e a Venezuela coincidem em que o Conselho de Segurança deve ser reformado, com o propósito de melhorar a representatividade dos membros, particularmente, os em desenvolvimento. Para esses dois países, isso ocorreria, se o numero de integrantes tanto dos membros permanentes quanto dos rotativos incrementasse segundo critérios de influência geopolítica. Venezuela entende que a América Latina encontra-se acéfala diante do CS, e confia no Brasil para que exerça essa liderança, por isso o apóia em sua candidatura à cadeira permanente. O direito de veto - dos atuais membros - é outro aspecto em que coincidem as opiniões, no sentido de que este seja revogado.

\footnotetext{
${ }^{29}$ Ata de Recife. Disponível em http://www.gobiernoenlinea.ve/miscelaneas/brasilvenezuela/brasilvenezuela6.html\#1. Data: 08/03/2010.
} 
Esses pontos chaves tratados pelos dois países, apesar de coincidentes em sua essência, são argumentados e trabalhados de forma diferenciada em suas agendas internacionais. Isso pode ser observado nas seguintes explanações: quando o Brasil defende a reforma do CS, por meio da ampliação do número de membros, o faz de forma ativa, com o interesse de integrá-lo. Para conquistar dito objetivo, promove vários tipos de comportamentos que o qualifiquem para o posto, tais como: participa em estudos relativos à reforma da ONU e em operações de paz; promove a paz por meio de ações preventivas; advoga pelos países em desenvolvimento; reitera em qualquer oportunidade a sua intenção; integra o grupo de países interessados no mesmo objetivo para trabalharem em conjunto; e angaria apoio.

Já a Venezuela, ao tratar sobre o tema da reforma, o faz de forma passiva, no sentido de não querer integrar a mudança, por não procurar a liderança regional ou mundial por essa via. Brinda, não obstante, apoio aos promotores e elabora justificativas sustentantes desse discurso. A chancelaria venezuelana argumenta que a composição e o modo de atuar do CS são impróprios para a realidade atual, porquanto são antidemocráticas e pouco representativas e responde a um conceito de segurança ultrapassado, o de segurança estatal, ao invés de segurança humana. Acrescenta que os métodos de trabalhos devem ser melhorados a fim de que ajam de forma preventiva e que o papel do Secretário Geral seja fortalecido.

Em alguns momentos do discurso venezuelano é perceptível algum grau de discordância com o do Brasil, quando sugere a perempção da ONU e a necessidade de que seja reinaugurada. À diferença do Brasil, entende Caracas, que a ação preventiva deve partir principalmente do Secretário Geral, ao invés do Conselho de Segurança. Fora isso, predomina o consenso. 


\section{Ações dos EUA no combate ao terrorismo, no Afeganistão e no Iraque}

O terrorismo é conceito de difícil definição, pois abrange diferentes tipos de entidades com ideologias, modos de ataque e alvos diferentes, que podem estar disseminados em células por todo o mundo. SUAREZ (2008) diz que "terrorismo pode ser compreendido como ação política extrema, que mina a possibilidade de diálogo”, mas o governo norte-americano trabalha com uma definição mais ambígua.

Segundo esse autor, “não havendo uma definição universalmente válida sobre terrorismo e principalmente sobre as características dos atores terroristas, essa categoria pode ser implementada na justificativa para intervenções no cenário internacional por atores que possuem capacidade para tal.”. A definição adotada pelos Estados Unidos ignora a complexidade do contexto político. Eles, aproveitando-se da dificuldade conceitual, procuram manipular e colocar vários atores sob a mesma categoria, como por exemplo: a base da Al Qaeda, as Forças Armadas Revolucionárias da Colômbia (FARC) e o Exército Revolucionário Irlandês (IRA). Essas são organizações que lidam com aspectos políticos particulares, entretanto são tratados igualmente como terroristas pelo Estado norte-americano. Além disso, qualquer ator que se associar a outra organização reconhecida como ameaça existencial passa a ser identificado como uma ameaça também, tais quais aqueles que se aproximam da Al-Qaeda - ator terrorista por excelência segundo os EUA por serem os autores dos atentados de setembro de $2001^{30}$.

O dia 11 de setembro será esquecido com dificuldade, porque representa a queda do mito da inviolabilidade do território norte-americano ${ }^{31}$ - tão destacado nas Primeira e Segunda Guerra Mundial e demais guerras externas de menor envergadura. A primeira atitude tomada pelo governo, após os atentados, para relativizar a sensação de insegurança, foi partir para a pronta ofensiva. Para tanto foram tomadas três medidas, de cunho nacional, segundo PECEQUILO (2005, p.375-376): a declaração de guerra, a convocação de ampla aliança nacional e a identificação e punição dos responsáveis. No âmbito internacional, os EUA deram

\footnotetext{
${ }^{30}$ SUAREZ, M.A.G. Artigo: America Latina frente aos desafios ao combate do Terrorismo internacional: Soberania versus intervenção. IPSA. 2008.

${ }^{31}$ PECEQUILO, C.S. A política externa dos Estados Unidos, cap. 8; p. 372-389. Ed. UFRGS. 2005. e Idem.
} 
início à construção da coalizão global, com vista ao combate do terrorismo internacional.

O principal alvo das investigações foi o terrorista internacional Osama Bin Laden, líder da organização Al-Qaeda e inimigo dos EUA. A estrutura terrorista possuía aliados e células regadas pelo mundo todo, em particular no Sudão, Paquistão e Afeganistão. A campanha da Al-Qaeda anti-norte-americanista é antiga e permanente, sendo responsabilizada por ataques ao World Trade Center, às embaixadas americanas na África e ao navio USS Cole ${ }^{32}$.

Os ataques ao Afeganistão foram resposta imediata à invasão do território americano, começaram em 7 de outubro de 2001. Os EUA buscaram expandir sua coalizão global antiterrorismo, demandando dos republicanos sua adesão ao multilateralismo - fundamental para a legitimação e efetivação das ações norteamericanas.

A operação antiterrorista no Afeganistão, denominada Liberdade Duradoura, tinha 3 objetivos: extinguir a Al-Qaeda e o regime Talibã; reconstruir a política e a economia afegã; e eliminar o terrorismo em escala mundial. Para tanto, era necessária, segundo Washington, uma estratégia multidimensional em que comungariam ações militares, políticas, econômicas e diplomáticas em aliança com organizações internacionais e países estratégicos. A comunidade internacional e as forças internas dos EUA respaldaram essa operação, por considerá-la justa diferente do que ocorreria mais adiante na operação contra o Iraque ${ }^{33}$. A coalizão aliada para combate apresentou esgotamento imediato, à medida que as metas foram cumpridas por meio da destituição do talibã do poder e a instauração de novo governo. Resolvidos esses problemas, restaram ainda os mais complicados: o combate ao terrorismo em escala global e a desarticulação da Al Qaeda.

As instituições norte-americanas - e de certa forma a comunidade internacional - perceberam que o ataque afegão não resolveria o problema do terrorismo, porquanto Al-Qaeda é um entre vários grupos. Além disso, para destruíla seria necessário desmantelar todas as suas células, de forma a minar seu financiamento e recrutamento, em âmbito global - e não apenas a situada no país afegão. Precisar-se-ia para a consecução desse objetivo de ações de inteligência,

\footnotetext{
${ }^{32}$ Idem, p. 378.

${ }^{33}$ Idem, p. 383-384.
} 
combate à lavagem de dinheiro e contraposição ideológica ao discurso terrorista ${ }^{34}$. Segundo PECEQUILO (2005, p. 384), “a guerra seria multidimensional, multilateral, e sustentada tanto no soft quanto no hard Power dos Estados Unidos e seus aliados.

Em setembro de 2002, o governo dos Estados Unidos lançou a doutrina Bush, nova Estratégia de Segurança Nacional, e segundo esse Presidente: “único caminho para a paz e a segurança é o caminho da ação.”, por meio de atos de prevenção e preempção $^{35}$. O Executivo norte-americano planejou novas operações militares em países hostis, e os principais cenários hipotéticos de conflito seriam: Iraque, Síria, Irã e Coreia do Norte. Dentre esses Estados, os EUA escolheram o Iraque, para ser o palco da primeira guerra preventiva ${ }^{36}$.

Sadam Hussein, presidente do Iraque, foi considerado associado à Bin Laden nos ataques, segundo afirmações do Departamento de Defesa. Inicialmente, essa informação não recebeu muita atenção, entretanto, com o intuito de justificar a guerra contra o Iraque em 2003, foi, logo, recuperada junto à alegação da elaboração do programa de armas de destruição em massa (ADMs), apesar de que os serviços de inteligência dos EUA negassem a ligação entre ambos os líderes e houvesse incerteza da existência das ADMs. ${ }^{37} \mathrm{O}$ real objetivo de Washington era a independência energética e a contenção do Irã. Em março de 2003, Bush anunciou que a negociação diplomática terminara e deu prazo de dois dias para Hussein renunciar ao poder, como isso não ocorreu, EUA iniciou a guerra com o ataque à Bagdá ${ }^{38}$. Apesar da previsão do Departamento de Defesa norte-americano de que a investida no Iraque e sua posterior reestruturação seriam rápidas, com poucos efetivos e baixas militares, a realidade demonstrou o contrário. Havia alta oposição à presença norte-americana dentro do país iraquiano e as forças xiitas, sunitas e curdas disputaram os espaços políticos deixados por Hussein, prolongando a guerra.

No primeiro quartel de 2002, a opinião pública interna norte-americana (em breve conquistada) nem a comunidade internacional compartilhavam da opção de outra guerra na Eurásia. Não houve ligação direta de apoio entre o conflito afegão e o iraquiano, haja vista, desde a derrota em 1991 e o sancionamento, o Iraque perdeu

\footnotetext{
${ }^{34}$ Idem, p. 384.

35 Idem, p. 395.

${ }^{36}$ Idem, p. 402.

${ }^{37}$ Idem, p. 378.

${ }^{38}$ Idem, p. 411.
} 
sua capacidade de agressão e projeção de poder externo, em nível regional e global ${ }^{39}$. O Conselho de Segurança das Nações Unidas (CS), em novembro de 2002, aprovou por unanimidade a dúbia resolução 1441, que estabelecia "sérias consequências” ao Iraque, caso não acatasse os termos da mesma, por meio de ação decisiva do CS para assegurar a paz e a segurança internacional. Essa redação foi considerada ambígua pelos demais membros da ONU, já que não delimitava o significado de "sérias conseqüências” nem “ação decisiva”. Para os contrários ao ataque, indicava a necessidade de resolução adicional para a declaração de guerra; para os EUA, ela legitimava $o$ ataque.

Após a queda do governo Hussein, a ONU enviou missão política dirigida pelo brasileiro Sérgio Viera de Mello, para promover a negociação entre os grupos que estavam levando o país à guerra civil. Mello, antes de falecer pelo atentado do carro-bomba à sede da missão, afirmou que a situação por ele encontrada era bastante precária e expressou preocupação quanto à fragmentação do território iraquiano e à segurança vulnerável do quartel-general da ONU em Bagdá. Ele sugeriu que o caminho para a democracia se desse com a transferência do poder para representantes do país e um cronograma para a saída das tropas. Era uma proposta apoiada pela Grã-Bretanha, porém rechaçada por Washington.

Os Estados Unidos atuaram na guerra preventiva do Iraque de forma agressiva e unilateral. Na realidade, o combate ao terrorismo serviu como justificativa do porquê os EUA precisavam expandir sua hegemonia no sistema e aumentar seu poder militar ${ }^{40}$. Destaca a autora PECEQUILO (2005, p. 392) que, no sentido de evitar a desmobilização social, os republicanos procuram atribuir-lhe continuidade - Bin Laden e depois Saddam Hussein -, de modo que a ameaça ficasse sempre no imaginário da sociedade. Em janeiro de 2002, Bush lançou o conceito de Eixo do Mal, que identificava como ameaças à segurança e inimigos a serem combatidos Estados autoritários detentores de projetos de hegemonia regional, ADMs assim como promotores do terrorismo internacional. Estes eram Irã, Iraque, Coreia do Norte, Líbia e Síria. O eixo latino compunha-se por Cuba, Venezuela e Brasil.

\footnotetext{
${ }^{39}$ Idem, p. 403.

${ }^{40}$ Idem, p. 392 e 393.
} 
O terrorismo alçados a categoria de inimigo mundial ${ }^{41}$ e como ameaça existencial abre espaço para que Washington realize ações no plano político interno e externo, as quais seriam injustificáveis e demandariam altas manobras políticas. Essa ameaça permite estabelecer medidas políticas legítimas e justificadas, e mais do que isso, o terrorismo tornou-se elemento chave para a legitimação de ações de intervenção no cenário internacional. Como ameaça difusa, politicamente, o terrorismo serve não apenas para os EUA desenvolverem sua própria política de intervenção no cenário internacional, mas também para outros atores o fazerem em contextos políticos distintos. ${ }^{42}$

O combate ao terrorismo norte-americano sob os argumentos da prevenção e preempção gerou crescente instabilidade mundial e acelerou a procura por soluções de segurança similares por todo o sistema. Resultou na proliferação de projetos nucleares, corridas armamentistas e grupos terroristas, fortalecidos pela ausência de progresso econômico e social, e do sentimento antiamericanista. O excesso de hard Power é contraproducente e facilita o reconhecimento dos EUA como único inimigo pelos terroristas.

Afirma PECEQUILO (2005, p. 389) que o combate ao terrorismo global, por ser tão disseminado e por ter diversos grupos independentes, levaria ao esgotamento global dessa campanha; e segue:

"Mesmo que o pressuposto da luta seja universalista nos casos mais antigos, a guerra limitarse-á a fronteiras e reivindicações preexistentes. Na hipótese do novo terrorismo, a batalha será mantida se ele tiver perfil semelhante ao de Laden. Não podemos esquecer que mobilizações de guerra, em quaisquer de suas feições, moderna ou tradicional, são custosas moral, política e economicamente e que a aparência de paz e estabilidade pode levar ao arrefecimento das tensões.”

${ }^{41}$ Idem, cap. 9, p. 391.

${ }^{42}$ SUAREZ, M.A.G. Artigo: America Latina frente aos desafios ao combate do Terrorismo internacional: Soberania versus intervenção. IPSA. Ano 2008. 
Além disso, como destaca SUAREZ (2008), o estudo sobre terrorismo contemporâneo ganhou maior relevância após os atentados de setembro de 2001. O conceito central analisado, porém, é o de terrorismo islâmico. Segundo esse autor, não existe terrorismo islâmico por si só; terrorismo é meio de violência utilizado para se obter ganhos políticos ou é tática de combate em conflitos de natureza assimétrica. Sugere este que o terrorismo está espraiado pelo mundo, sem estar, essencialmente, vinculado ao islamismo. Na América, consoante PECEQUILO (2005, p. 446), o foco concentra-se sobre as questões do narcoterrorismo colombiano e a influência de Hugo Chávez, da lavagem de dinheiro na tríplice fronteira do Cone Sul e o desenvolvimento do programa nuclear brasileiro.

Conforme SUAREZ (2008), o relato de 4/2005 sobre a situação do terrorismo na América Latina, do Departamento de Estado norte-americano, atesta que, ainda que possam ser identificados crimes como lavagem de dinheiro, contrabando, compra ilegal de armas. Não foi possível a identificação de células operacionais de grupos terroristas. A América Latina faz parte da esfera de influência imediata da política externa norte-americana. É certo que o hemisfério sul possui importância estratégica para os EUA, mas se for comparada à atenção dada ao oriente, pode-se dizer que a América Latina não está na ordem do dia.

\subsection{Brasil}

O Brasil, por breve espaço de tempo, por causa da inação ou atitudes duvidosas e durante as eleições que deram início ao mandato de Luis Inácio Lula da Silva, foi considerado parte do eixo do mal latino. A vitória de Lula gerou essa classificação, porquanto se temia sua figura de líder sindical da esquerda ligado a tendências radicais que levariam a aproximação com os tradicionais inimigos do governo Bush: Chávez e Castro ${ }^{43}$, sua postura diante dos países do Oriente Médio, a concentração islâmica na tríplice fronteira responsável pela lavagem de dinheiro, e o programa nuclear reativado pelo Estado.

A importância política e estratégica da região para o Brasil, o relacionamento e a localização das comunidades judaica e árabe no Brasil e os interesses econômicos são três elementos, tomados em consideração no relacionamento do Brasil com o

\footnotetext{
${ }^{43}$ Idem, p. 395, citando o Washington Times.
} 
Oriente Médio. Inclusive, o governo Lula retomou o interesse sobre o mundo árabe e organizou, em maio de 2005, a primeira Cúpula da América do Sul e dos Países Árabes (Caspa). ${ }^{44}$

Segundo SUAREZ (2008), "na esteira da Guerra Global contra o Terrorismo, o tema da relação da tríplice fronteira (do cone sul) com a ideia de terrorismo islâmico e a questão da Colômbia e o conflito com as FARC vieram à tona”. A fronteira do Cone Sul, para o Brasil e seus parceiros regionais, detém importância em aspectos tanto políticos quanto de segurança, e qualquer assunto relacionando-a implica intervenção brasileira. Trasladar o conceito de terrorismo islâmico para a América Latina, tal como usado em outros contextos, sem considerar o aspecto político regional, deforma a realidade, visto que, até o momento, o que se apresenta como presença deste na região é o emprego de formas de autofinanciamento, por exemplo, o contrabando e a lavagem de dinheiro, o que não permite ignorar sua presença no continente.

A posição brasileira diante dos órgãos multilaterais deixa claro que os limites da guerra global contra o terrorismo liderada pelos EUA não podem ser minimizados de maneira inconteste e, principalmente, não podem criar um vácuo jurídico no qual ações no plano internacional possam ser dispostas de maneira unilateral, como diz SUAREZ. A política estratégica brasileira de combate ao terrorismo não pode imitar a norte-americana, e, sim, visar estabelecer um equilíbrio político na região a fim de que as ações de intervenção subsidiadas pelo combate ao terrorismo não se tornem legítimas aos olhos da comunidade internacional. ${ }^{45}$

O período que remonta aos ataques terroristas de 11 de setembro de 2001 contra os Estados Unidos e à guerra do Afeganistão ocorreu durante o governo Fernando Henrique Cardoso (FHC). O Brasil, nessa ocasião tomou a iniciativa de invocar o Tratado Interamericano de Assistência Recíproca (TIAR) após os atentados, em solidariedade aos Estados Unidos e também os apoiou na guerra contra o Afeganistão, com base no repúdio aos atos terrorista segundo entendimento de BERTAZZO (2007). Já conforme explana HIRST (2006, p. 108), a atitude brasileira

\footnotetext{
${ }^{44}$ MESSARI, N. O Brasil e o mundo árabe. Relações Internacionais do Brasil: Temas e Agendas. Orgs. ALTEMANI, H. e LESSA, A.C. 2006. Volume 1, Cap. 8, p. 244-245.

${ }^{45}$ SUAREZ, M.A.G. Artigo: America Latina frente aos desafios ao combate do Terrorismo internacional: Soberania versus intervenção. IPSA. Ano 2008.
} 
em relação aos ataques do 11/09 foi de solidariedade e de maior aproximação dos valores políticos ocidentais, entretanto, diminuiu quando os EUA iniciaram os preparativos militares para atacar o Afeganistão e, posteriormente, o Iraque - a fim de derrubar Saddam Hussein ${ }^{46}$. Pode-se dizer que explanação mais condizente com a postura do Itamaraty com relação à guerra contra o terrorismo foi a de PECEQUILO (2005, P. 410), quando afirma que

“Durante todo o período de encaminhamento da guerra e com sua eclosão, a diplomacia brasileira manteve uma posição equilibrada, sem deixar de ser crítica das atitudes unilaterais norte-americanas. A opção do multilateralismo foi reforçada, indicando-se a preferência da resolução dos impasses via ONU. A posição do governo foi criticada por alguns especialistas brasileiros e norte-americanos que defendiam uma escolha pró-alinhamentos como as de Portugal e Espanha, desconsiderando o perfil clássico de atuação da política externa nacional desde os anos 1960: vocação pacífica, multilateral e autonomista”.

O Brasil perante essas situações respondeu de duas maneiras: primeiro reforçou a defesa do foro multilateral para tratamento do terrorismo, e segundo apontou o impacto humanitário das ações de intervenção militar, além de robustecer as medidas de controle à lavagem de dinheiro no Brasil destinada ao financiamento do terrorismo ${ }^{47}$. Segundo HIRST (2006, p. 109), a estratégia brasileira diante desse panorama foi a de evitar o alinhamento à política de defesa dos EUA, mas asseverou o apoio à guerra contra o terrorismo, liderada pela Casa Branca.

O presidente Lula foi empossado no período marcado pela reação dos EUA aos atentados por eles sofridos. Mais precisamente, quando os norte-americanos estavam prestes a iniciar a guerra contra o Iraque, estourada em março de 2003. A agenda política internacional estava dominada pela guerra contra o terror, assim

\footnotetext{
${ }^{46}$ HIRST, M. As cinco “AS” das relações Brasil - Estado Unidos: aliança, alinhamento, autonomia, ajustamento e afirmação. Relações Internacionais do Brasil: Temas e Agendas. Orgs. ALTEMANI, H. e LESSA, A.C. 2006. Volume 1, Cap. 4, p. 91-127.

${ }^{47}$ Idem, p. 108-109.
} 
denominada pelo presidente $\mathrm{W}$. Bush. O governo Lula teve iniciativas relevantes nesse contexto. Uma de cunho simbólico: a entrevista em rede de rádio e televisão anunciando o início da invasão do Iraque pelos EUA e seus aliados. Nessa entrevista, o Presidente condenou a invasão e defendeu a ação multilateral e pacífica, por intermédio das Nações Unidas, na resolução de todos os conflitos internacionais. ${ }^{48}$

Essa não foi uma ação despercebida, porque poucos foram os países que tomaram posição tão clara. Diante dessa atitude, os analistas estiveram receosos quanto à possível reação dos EUA. A atitude do governo brasileiro, entretanto, tem sido a de manter a mesma posição com relação à guerra contra o Iraque. Assim sendo, no discurso de abertura da Assembleia Geral da ONU, em setembro de 2003 e durante a reunião da Liga Árabe, em dezembro do mesmo ano, o Brasil condenou o uso da força e o desafio dos EUA às Nações Unidas, no iniciou a guerra, e, quando foi deposto Saddam Hussein e seu regime. O governo brasileiro defendeu a volta da soberania iraquiana com um representante legítimo e a saída das forças armadas estrangeiras. $^{49}$

Em razão da retomada do interesse brasileiro pelos países árabes, Lula e Amorim realizaram diversas viagens ao Oriente Médio, a países como Emirados Árabes Unidos, Síria, Líbano, Egito e Líbia, haja vista a potencial troca comercial; as comunidades existentes no Brasil; o peso político regional; e os laços entre os representantes de Estado, respectivamente. Somado a isso houve o convite para a participação da Caspa, celebrada em 2005. Merece especial destaque, nas iniciativas brasileiras de reaproximação, a Declaração de Brasília, no ponto em que trata da atitude americana no mundo árabe. Essa declaração apoiou a nova administração iraquiana, mas advogou maior envolvimento da ONU na reconstrução do País; condenou a Syria Accountability Act (norte-americano) e condenou o terrorismo, mas reafirmou o direito dos povos a resistirem à ocupações estrangeiras. ${ }^{50}$

O Ministro das Relações Exteriores Celso Amorim, no seu discurso de posse, afirmou o compromisso de promover o banimento das ADMs; de impulsionar o esforço de desarmamento, sobretudo o nuclear; e de participar na luta contra o

\footnotetext{
${ }^{48}$ MESSARI, N. O Brasil e o mundo árabe. Relações Internacionais do Brasil: Temas e Agendas. Orgs. ALTEMANI, H. e LESSA, A.C. 2006. Volume 1, Cap. 8, p. 257-258.

49 Idem, p. 258-259.

${ }^{50}$ Idem, p. 259-260.
} 
terrorismo e o crime organizado, com base na cooperação e no Direito Internacional. O caminho para conquistar esses objetivos, segundo o Ministro, é a solução pacífica de controvérsias - por ser pilar da diplomacia brasileira. Ele observa com tristeza a deterioração da situação do Oriente Médio, e considera que não se deve abandonar a via pacífica e do diálogo, sob pena de perpetuar-se o sofrimento das populações envolvidas e de desencadear forças incontroláveis com enorme potencial desestabilizador para a região e para o mundo. Portanto, vê-se necessário resgatar a confiança nas Nações Unidas e reafirmar o Conselho de Segurança como único órgão legalmente habilitado a autorizar o uso da força, quando todos os outros esforços se hajam totalmente esgotado. ${ }^{51}$

\subsection{Venezuela}

O presidente Hugo Chávez e seu ex-chanceler Roy Chaderton manifestaramse contrários a guerra contra o Iraque, assim que estourou, em 2003. O presidente pronunciou-se contra a invasão do Iraque, durante o discurso que fez no ato de entrega dos documentos de propriedade de terras urbanas e créditos para realização de reformas de moradias e formação de microempresas e afirmou que a única guerra válida é contra a pobreza, a fome e a morte. Os efeitos da guerra na Venezuela são inestimáveis, principalmente no setor petroleiro, em razão da queda do preço do petróleo. Essa baixa justifica-se na expectativa do rápido cessar-fogo - por mais que o mandatário norte-americano comentasse que poderia ser uma situação de longa duração. ${ }^{52}$

Segundo o ex-chanceler Roy Chaderton, a Venezuela é a favor da solução pacífica da guerra no Oriente Médio e de que o lugar propício para esse tipo de ação é sob o marco da ONU. Para ele, o sistema internacional foi afetado porquanto a opção da guerra foi à margem da ONU, uma opção unilateral dos EUA, GrãBretanha e Espanha, apesar de quem a promoveu invocasse a resolução 1441. Acredita Chaderton que essa atitude abriu precedente para que outros países atuem

\footnotetext{
${ }^{51}$ Discurso proferido pelo Embaixador Celso Amorim por ocasião da Transmissão do Cargo de Ministro de Estado das Relações Exteriores, em 01/01/2003. Disponível em: http://www.mre.gov.br/portugues/politica_externa/discursos/discurso_detalhe3.asp?ID_DISCURSO= 2032. Acesso em: 10/03/2010.

${ }^{52}$ MARGIOTTA, N. Artigo: Venezuela se pronuncia contra la guerre de Irak. 23/03/2003. Disponível em: http://www.mail-archive.com/latina@peacelink.it/msg01379.html. Acesso em: 14/03/2010
} 
fora do âmbito da ONU, ou mesmo da Organização dos Estados Americanos (OEA), sentindo-se livre para descumprir com os compromissos internacionais. Tudo que contribua para a tensão internacional causam desvantagens para países pequenos, como a Venezuela.

Em discurso na Assembleia Geral da ONU de 2005, o presidente Hugo Chávez declarou a urgência de enfrentar eficazmente o terrorismo internacional, mas destacou que não deve ser usado esse argumento para gerar ataques militares injustificados e violadores de direitos humanos. O fim do terrorismo, segundo ele, somente acontecerá com a cooperação e o fim do sistema de "duas medidas, dois pesos” aplicado por alguns países do Norte sobre o problema. O País reclamou nova ordem econômica internacional, mas também reconhece a imprescindibilidade de nova ordem política internacional. Por isso, chamou aos povos para impedir que alguns poucos Estados tentem reinterpretar os princípios de Direito Internacional, que sustentam doutrinas como a "Guerra Preventiva" - sob a qual constantes ameaças a qualquer país são praticadas - e a “Responsabilidade de Proteger”. Chávez ainda questiona quem e como será essa proteção. ${ }^{53}$

Conforme notícia da Voltairenet.org, Hugo Chávez apoiou a tese de Thierry Meyssan de que os atentados de setembro de 2001 foram de autoria norteamericana $^{54}$. O motivo que levou os norte-americanos à auto-sabotagem era a necessidade de justificativa para as agressões ao Afeganistão, ao Iraque e as ameaças contra a Venezuela. Chávez apóia sua crença tanto na tese do autor como na argumentação de cientistas e arquitetos famosos que afirmam a impossibilidade do desastre sem apoio de Washington. O chanceler Nicalás Maduro salienta a necessidade de mais investigações independentes para apurar a autoria dos atentados. Chávez, segundo este artigo, é crítico da política exterior norte-americana e constantemente condenou as ações militares dos EUA no mundo, porque servem para garantir sua hegemonia e expandir o capitalismo. ${ }^{55}$

\footnotetext{
${ }^{53}$ Discurso do presidente da Venezuela Hugo Chávez na Sexagésima Assembleia Geral das Nações Unidas. Ano 2005. Disponível em: http://es.wikisource.org/wiki/Discurso_del_Presidente_Hugo_Ch\%C3\%A1vez_en_la_Asamblea_Gen eral_de_la_ONU_de_2005. Acessado em: 10/03/2010.

${ }^{54}$ Acompanham a mesma tese os mandatários sheik Zayed dos Emirados Árabes Unidos, Al-Assad da Síria e Ahmadinedhjad do Iran.

${ }^{55}$ VOLTAIRENET.ORG. Artigo: Hugo Chávez apoya públicamente las tesis de Thierry Meyssan sobre el 11 de septiembre. Disponible em: http://www.voltairenet.org/article143442.html e o portal El
} 
Segundo Cardozo E. (2006), os ataques de 11 de setembro ocasionaram grande mudança na política de segurança norte-americana - o terrorismo como ameaça capaz de fortalecer a real polítik de W. Bush. Em 2003, o documento da Estratégia de Segurança Nacional dos EUA gerou receio e repulsa do governo venezuelano, haja vista a guerra preventiva, o projeto de ampliação do livre comércio e possível atuação individual norte-americana, caso se sentissem ameaçados. A insistência de Washington em qualificar as guerrilhas colombianas em terroristas e a autorização para usufruir dos recursos militares oferecidos pelo "Plan Colombia”, após o 11/09, intensificaram o discurso anti-norte-americano do governo venezuelano, que enxergou a Colômbia como uma desculpa da Casa Branca para realizar intervenção em território venezuelano. Caracas criticou qualquer iniciativa que significasse materializar algum tipo de ingerência, justificada internacionalmente por razões de segurança seja democrática, seja de direitos humanos, seja contra o terrorismo. $^{56}$

O governo de Hugo Chávez afasta-se dos processos hemisféricos, por considerá-los neutros e contrários aos seus - de corte radical com relação à luta antiimperialista e à crise do capitalismo. Em razão disso, a Venezuela prefere manter relações especiais com países como China, Iran, Coreia do Norte e Rússia; fortalecer a Alianza Bolivariana para los Pueblos de Nuestra América (ALBA); e promover o multilateralismo nada liberal e sem a presença dos EUA. A tese venezuelana consiste em impulsionar uma lógica diferente a norte-americana. Caracas opõe-se a participação dos EUA nos assuntos de segurança e defesa regional. Para Washington, não obstante, a Venezuela é um país problemático, principalmente, se levar em consideração os assuntos de segurança, valores democráticos e desenvolvimento. ${ }^{57}$

Reloj.com, Chávez asegura que Bush planeó los atentados del 11-S. 13/09/2006. Disponível em: http://www.elreloj.com/article.php?id=20618 Acesso em: 14/03/2010.

${ }^{56}$ CARDOZO, E. La agenda de seguridad de Venezuela-Colombia en el contexto de la subregión andina e Brasil (2000-2005). Insituto Latinoamericano de Investigaciones Sociales (ILDIS). CaracasVenezuela. 2006.

${ }^{57}$ MÉNDEZ, C.A.R. Artigo: Venezuela y la Agenda de Seguridad del Presidente Obama. Instituto Latinoamericano de Investigaciones Sociales (ildis). 2009. 


\subsection{Análise comparativa}

O combate ao terrorismo, em especial o islâmico, por parte dos Estados Unidos, envolveu as diversas regiões do mundo na luta e na mira das investigações de núcleos terroristas. A América Latina não ficou fora, tanto do ponto de vista das ações e medidas de combate quanto do debate. Os países, como o Brasil e a Venezuela, apresentaram suas visões e desenvolveram ações diante o assunto.

O Brasil e a Venezuela foram contrários a todo tipo de terrorismo e solidários às vítimas dos atentados. Defenderam que as retaliações a serem tomadas pelo governo da Casa Branca deviam partir de decisões tomadas por organismos multilaterais, como a ONU. Por isso foram contrários aos ataques impetrados contra o Iraque, haja vista serem contrários a posição do Conselho de Segurança e das Nações Unidas de modo geral.

Lula e Chávez condenaram abertamente a atitude norte-americana, mas distanciaram-se no embasamento de seus argumentos. O governo venezuelano contesta a autoria dos atentados de 11 de setembro, inclusive acusa os Estados Unidos de serem os autores, a própria chancelaria demandou mais investigações sobre o assunto. A Venezuela age assim porque os países do oriente médio atacados são produtores de petróleo - fonte energética de interesse norte-americano - e membros da OPEP, isto é, trade maker do mercado de petróleo e, portanto, afetam o principal item de comércio venezuelano, por causa das flutuações produzidas nos preços desse produto.

Além disso, a aproximação de Chávez dos países do “eixo do mal” produz mal-estar aos norte-americanos, na medida em que o faz atacando o sistema capitalista. A política de governo chavista visa ao socialismo do século XXI, voltado ao combate da pobreza, das desigualdades e da proteção ao meio ambiente. Para a Casa Amarela, os Estados Unidos reagem agressivamente a todo modelo que difere de sua política de expansão capitalista e, por isso, a Venezuela sente-se ameaçada com as bases militares próximas a fronteira venezuelana-colombiana e o Plan Colômbia, que significa para ela um alerta de possível ataque norte-americano ao País.

Já a atitude brasileira é diferente, sua aproximação com países do Oriente Médio faz parte da ampliação das relações internacionais, dentro das políticas do 
Itamaraty de intensificar as relações sul-sul. Sua justificação está na ampliação de laços culturais e comerciais e na disposição de negociar a paz por ser um país neutro, que agrupa, em harmonia, nacionais e descendentes dessas regiões. O Brasil igualmente não contesta o modelo capitalista, toma atitudes claras de combate aos meios de enriquecimento do terrorismo e adverte que é contrário ao uso de tecnologia nuclear para fins armamentistas.

Essa atitude brasileira, de certa forma, acalma Washington. Cabe destacar que, atualmente, a administração norte-americana não se guia pela Venezuela de Chávez para direcionar a política para América Latina e sim pelo Brasil de Lula e pelo México de Calderón. ${ }^{58}$.

58 Idem. 


\section{Rodada Doha da OMC}

A Organização Mundial de Comércio (OMC) começou suas atividades em $1^{\circ}$ de janeiro de 1995, ao substituir e ao incorporar o GATT, com a função de administrar o sistema multilateral de comércio resultante da Rodada Uruguai $(1986 / 93)^{59}$. A Rodada Doha, lançada em novembro de 2001, foi a primeira rodada de negociação no âmbito da OMC e visa a liberalização do comércio mundial em prol do desenvolvimento - também denominada "Rodada do Desenvolvimento".

As principais funções da OMC são gerenciar os acordos multilaterais e plurilaterais de comércio negociados por seus membros, particularmente sobre bens (Gatt), serviços (Gats) e direitos de propriedade intelectual relacionados com o comércio (Trips); deslindar diferenças comerciais; atuar como fórum para negociações sobre temas já cobertos pelas regras multilaterais de comércio e sobre novas questões; supervisionar as políticas comerciais nacionais; e cooperar com o Banco Mundial e o FMI na adoção de políticas econômicas em nível mundial ${ }^{60}$.

A OMC constitui-se como organização permanente, com personalidade jurídica própria e possui o mesmo status do Banco Mundial e do FMI. Os compromissos sob seus auspícios são absolutos e permanentes, e o seu sistema de solução de controvérsias é mais efetivo e menos sujeito a bloqueios. Os Estados signatários são denominados membros. Suas normas dizem respeito ao intercâmbio de mercadorias e serviços, e assuntos de direitos de propriedade intelectual relacionados com o comércio. Os acordos da OMC são subscritos integralmente pelos membros, cujas únicas exceções são as negociações sobre carne bovina, produtos lácteos, aeronaves civis e contratação pública, denominados plurilaterais e cuja adesão é voluntária ${ }^{61}$.

A vigilância quanto ao cumprimento dos acordos multilaterais e dos compromissos assumidos é exercida pelos próprios membros da OMC. Para isso, a transparência é fundamental. O responsável por realizar regularmente avaliações das políticas comerciais dos membros é o Órgão de Exame das Políticas Comerciais (TPRB) da OMC, com base em dois instrumentos: a declaração das políticas

\footnotetext{
${ }^{59}$ RÊGO, E.C.L. Artigo: Do GATT à OMC: o que mudou, como funciona e para onde caminha o sistema multilateral de comércio.

${ }^{60}$ Idem.

${ }^{61}$ Idem.
} 
adotadas, apresentada pelo governo do país examinado e um informe minucioso, preparado de maneira independente pela Secretaria da OMC. Após este exame, chamado de Trade Policy Review Mechanism (TPRM), os dois informes são publicados, juntamente com a Ata da reunião do TPRM, e, com isso, aumenta-se a transparência dos regimes comerciais dos membros da OMC, permitindo maior vigilância mútua ${ }^{62}$. A periodicidade do exame depende da participação do país no comércio internacional, no caso do Brasil é a cada 4 anos e da Venezuela, 6.

Por meio dos compromissos assumidos no âmbito da OMC, os Estadosmembros garantem maior acesso aos mercados de outros países, assim como limitam de modo significativo o espaço de ação das nações na definição das políticas econômicas com efeito no comércio, ao restringir medidas discricionárias e protecionistas. Por conseguinte, os policy makers, ao definirem as políticas nacionais, precisam levar em conta tanto as demandas e necessidades domésticas quanto os compromissos assumidos com seus parceiros internacionais. Os governantes precisam combinar sua retórica à nova realidade, de modo a evitar que os esforços para melhorar a competitividade externa dos produtos nacionais sejam contestados ou neutralizados pelos demais membros, mesmo que não violem qualquer compromisso acertado. Assim afirma RÊGO que “as medidas de comércio exterior precisam estar em sintonia com os compromissos multilaterais na prática (de facto), na lei (de jure) e no marketing" 63 .

A Rodada de Doha, estabelecida em novembro de 2001 - meses após os atentados terroristas contra os EUA - e com a expectativa de finalizar em 2005, refletiu a determinação dos governos dos Estados em superar diferenças e cooperar para tornar o comércio em efetivo instrumento de desenvolvimento, com a intenção de dar atenção especial aos direitos dos países em desenvolvimento ${ }^{64}$. Afirma CAMPOS (2008) que o regime do comércio da Guerra Fria foi considerado componente essencial de uma ordem internacional estabelecida a partir do compromisso com o desenvolvimento, que, por sua vez, foi associado ao tema da segurança -compromisso reafirmado, em Doha, após os atentados sofridos pelos

\footnotetext{
${ }^{62}$ Idem.

${ }^{63}$ Idem.

${ }^{64}$ CAMPOS, T.L.C. Artigo: A rodada de Doha: dificuldades e avanços na negociações agrícolas entre países desenvolvidos e em desenvolvimento. 2008.
} 
norte-americanos. Nesse momento, por causa dos atentados, o tema da segurança, novamente, alinhara-se ao do comércio.

A Rodada do Desenvolvimento tinha previsto durar 3 anos, entretanto continha uma agenda ampla, que superou a cobertura de temas da Rodada Uruguai. Os temas em pauta sugeridos pelos países em desenvolvimento foram: as responsabilidades corporativas das transnacionais; relações entre comércio e pobreza; e relações entre comércio, FMI e Banco Mundial. Os países europeus manifestaram interesse em discutir assuntos como comércio e meio ambiente; facilitação de comércio; leis de concorrência; e liberalização de investimentos. Mas o principal assunto em destaque foram as questões pendentes relativas à liberalização do mercado agrícola e dos serviços, que estenderam a negociação da rodada até a atualidade.

Pela primeira vez, a questão de práticas comerciais prejudiciais ao grupo de nações em desenvolvimento seria o ponto central das discussões. Os países ricos, em geral competitivos em produtos industrializados e de alta tecnologia, conseguiram a abertura de novos mercados externos, enquanto os países em desenvolvimento, fortes no setor agrícola, continuaram impossibilitados de exportar todo seu potencial devido aos subsídios e barreiras que tornaram seus produtos menos competitivos. Assim como afirma CAMPOS (2008)

“As assimetrias econômicas só podem ser equacionadas através da construção de regras que atendam à ampla gama de interesses dos países membros, o que, em larga medida implica concessões dos países desenvolvidos para aqueles em desenvolvimento. As dificuldades das negociações agrícolas configuram um ponto de inflexão nessa lógica. A não-concessão por parte dos países desenvolvidos pode, sim, comprometer o regime, pois desqualifica seus objetivos e, portanto, sua legitimidade.”

Os países desenvolvidos, até a Rodada de Doha, determinavam, em sua maioria, os temas negociados e os acordos. Mas foi nessa Rodada em que se 
percebeu a reconfiguração das forças, por meio do ativismo político de países emergentes com capacidade econômica e política de modificar os fluxos das negociações comerciais, como Brasil, Índia e China. Além destes, também se viu aumentar o ativismo político de países menos desenvolvidos da África, Caribe e Pacífico. O novo cenário das negociações comerciais antagoniza entre as demandas dos países em desenvolvimento e os interesses das nações desenvolvidas, sendo a harmonização de ambos o desafio dessa Rodada ${ }^{65}$.

As conversações fundamentaram-se em 3 bases. A primeira delimita os temas a serem discutidos. De dezenove, iniciar-se-ia com sete temas - cujos processos negociais gerariam maiores complicações -, relegando-se os demais a negociações futuras. Desses sete, cinco ficaram subordinados a que o acordo de um deles estaria condicionado ao acordo dos demais, sendo esta a segunda base - a da condicionalidade. Finalmente, os Estados acordaram que as negociações seriam coordenadas pelo Comitê de Negociações Comerciais ${ }^{66}$.

Os países membros da OMC dividiram-se em dois grandes grupos de negociação: os que defendiam a liberalização com exceções, composto pelo Grupo de Cairns, pelos EUA, pelos importadores de alimentos e pelos que sofriam problemas de segurança alimentar; e a União Européia. A idéia era estabelecer os termos da liberalização com exceções para alguns grupos e pressionar os europeus, por meio de concessões em outras áreas de seus interesses, como a de serviços ${ }^{67}$.

Em reunião realizada em Cancun, no mês de setembro de 2003, os Estados Unidos e a União Européia divulgaram manifesto conjunto sobre o comércio agrícola, ao qual esperavam que os países em desenvolvimento viessem a aderir, o que não ocorreu. Isso alterou o equilíbrio de ambos os grupos, pois a aliança dos Estados Unidos com a União Européia não procurava mais a liberalização, mas garantias para a continuidade do protecionismo do setor agrícola ${ }^{68}$. A proposta absorvia poucas sugestões dos países em desenvolvimento com relação aos três pilares do acordo agrícola: acesso a mercados; apoio doméstico e subsídios às exportações. As propostas dos EUA e da EU visavam acomodar as mudanças

\footnotetext{
${ }^{65}$ Idem.

${ }^{66}$ Idem.

67 Idem.

${ }^{68}$ Idem.
} 
ocorridas nas suas políticas agrícolas dos anos 90: a agenda 2000 e a Reforma Fischler da Política Agrícola Comum (PAC), da EU e a Farm Bill de 2002, dos EUA.

Em contrapartida, com liderança brasileira, indiana e chinesa, foi formado o G20 que buscaria retornar as negociações agora em outros termos. A novidade em Cancun foi a estréia desse grupo de pressão. Reunidos decidiram apresentar texto alternativo de modalidades, em função da percepção de que o texto conjunto da EUA-EU não incorporava as propostas por eles sugeridas - cujo eixo central é a eliminação de subsídios, tanto os dirigidos às exportações quanto os subsídios domésticos com efeito exportador.

A divergência não estava no formato das negociações de Doha, mas na postura adotada pelo principal participante (os Estados Unidos) naquele momento. Em janeiro de 2004, Washington reanalisou a aliança com os europeus e criou condições para a negociação, o que determinou “os pacotes de julho 2004”. O principal resultado do pacote foi o acordo acerca da fórmula para os cortes das tarifas. Cabe destacar que isso foi fruto de concessões européias e indianas, entretanto condicionadas às negociações de outros mecanismos protecionistas, como as salvaguardas e fórmulas diferenciadas para os chamados produtos sensíveis, tropicais e especiais.

Em junho de 2007, Brasil, UE, EUA e Índia, compuseram o G4, reuniram-se em Postdam, com o objetivo de retomar as discussões e destravar a Rodada Doha. A reunião acabou dois dias antes do previsto, quando Brasil e Índia decidiram se retirar, por causa, mais uma vez, do impasse na questão dos cortes de subsídios e na redução de tarifas que levou ao colapso das negociações.

Como afirma CAMPOS (2008), as dificuldades da Rodada de Doha não são determinadas por sua agenda ou pelo formato das negociações, mas pelo compromisso político dos Estados com a continuidade do processo negocial. Segundo essa analista, não obstante utilizar extraordinariamente os subsídios, a União Européia admitiu, desde o começo das conversações, que um acordo para a redução dos subsídios era preciso, condicionando-o àquele referente aos créditos e garantias de exportação. A questão dificultou-se em Cancun, quando os EUA expandiram seu programa de crédito aos exportadores e propuseram, com a Europa, 
que as negociações de corte nos subsídios fossem conjuntamente com aquelas destinadas aos cortes nos programas de crédito e de garantias às exportações.

A crise de 2008 trancou a pauta de negociação da Rodada do Desenvolvimento. Em meio à crise, o G-20 indicava que Doha era um dos pilares da retomada e da reforma do sistema multilateral e a meta era concluir os acordos até o fim de 2010. Não houve avanços em 2009, e foi cancelada a reunião de ministros de estado, de março de 2010, e adiada para 2011. O jornal Estado de São Paulo afirma que, após 9 anos e varias reuniões, os governos não sabem o que fazer com o processo que garantia gerar bilhões de dólares em abertura de mercado e redução de pobreza. Alguns afirmam que o culpado pelo fracasso é o governo americano, por exigir abertura significativa de Estados emergente, sem contrapartida. Pascal Lamy, diretor-geral da OMC, estava preocupado de que a crise proliferasse tratados bilaterais discriminatórios, que substituiria o sistema multilateral por uma rede de acordos. $^{69}$

\subsection{Brasil}

O Brasil foi signatário do acordo inicial do GATT em $1947^{70}$ e da OMC em 1995. Até a presente data, registrou 5 Exames das Políticas Comerciais e atuou perante o órgão de solução de controvérsias 24 vezes como reclamante, 14 como reclamado e 54 como terceiro. Pelo fato da política externa brasileira tender ao multilateralismo, é forte atuante nessa organização internacional. Segundo SATO E. (2006, p.153), com a criação da OMC, coincidiu o novo modelo da economia brasileira. A participação brasileira foi proativa na Rodada Doha, marcou igualmente a mudança do comportamento dos países em desenvolvimento, dentre eles o Brasil, uma vez que estes não mais endossam simplesmente as propostas dos países ricos, sem garantir vantagem em troca.

Em 1994, iniciou-se o processo de estabilização das condições macroeconômicas nacionais que de forma gradual reduziu a importância do câmbio como ferramenta do comercio exterior. A política comercial foi observada como questão estrutural e a posição brasileira no mercado internacional dependeu do

${ }^{69}$ O Estado de São Paulo, OMC, em risco, admite: Doha acabou, 25/02/2010.

${ }^{70}$ VALLS, L. Artigo: Histórico da Rodada Uruguai do GATT. Estudos em Comércio Exterior. 1997 Vol. I, n. 3, jul/dez. 
profissionalismo e das condições negociais dos seus produtos. Tanto ao ativar o órgão de soluções de controvérsias quanto ao negociar nas rodadas, diminuíram o espaço de manobra compensatória das deficiências estruturais e a falta de competitividade. $^{71}$

A principal atividade comercial brasileira no comercio exterior provém do setor de agrobusiness. Este detém tecnologia e produtividade que o torna tão competitivo quanto o dos países industrializados; representa 30\% do PIB brasileiro e funciona como dínamo da economia. O fim de subsídios e proteções é atraente, pois, estima-se que, ao reduzir a proteção apenas na agricultura, o mundo produziria aproximadamente $65 \%$ dos ganhos que seriam obtidos com a liberação total do comércio global.

O Brasil atua na OMC porque tem capacidade depois de negociar o desfecho de processos com qualquer país, por isso acredita nessa organização. A nação possui bons juristas, economistas, grandes especialista em OMC que permitem ao Brasil fazer essa aposta. Já foi vítima de várias violações comerciais, no entanto, sua condição o permite tentar ganhar no processo. A Organização é importantíssima para a política externa brasileira, que investe cada vez mais em processos multilaterais desse tipo, porque está construindo boa capacidade negociadora.

As expectativas e incertezas em volta da Rodada Doha em relação às questões difíceis não correspondem ao fracasso da organização, mas à dificuldade em compaginar interesses dos membros da comunidade internacional. ${ }^{72}$ Apesar da crença do Chanceler Amorim na possibilidade de concluir a Rodada Doha em algum momento, o Brasil procura meio de atender algumas das expectativas de desenvolvimento em torno da Rodada. O Ministro anunciou que, até meados de 2010, o País outorgará tratamento “duty-free-quota-free”, com abertura de 80\% de todas as linhas tarifárias, aos Países de Menor Desenvolvimento Relativo. Esse percentual aumentará progressivamente pelos próximos 4 anos, até cobrir a

\footnotetext{
${ }^{71}$ SATO, E., De GATT para OMC e a agenda do Brasil no comércio internacional. Relações Internacionais do Brasil: Temas e Agendas. Orgs. ALTEMANI, H. e LESSA, A.C. 2006. Volume 2, Cap. 1 p. 153.

${ }^{72}$ Idem, p. 155.
} 
totalidade das linhas tarifárias. Com isso, espera-se que os países desenvolvidos sigam o exemplo. ${ }^{73}$

\subsection{Venezuela}

A Venezuela é membro fundador de OMC, porém esta não representa um dos principais órgãos de sua atuação no âmbito multilateral. Entregou 2 Exames de Políticas Comerciais, um em 1996 e o outro em 2002. Fez pouco uso do mecanismo contencioso: atuou como reclamante uma vez - em conjunto com o Brasil, contra os Estados Unidos, sobre o comércio de combustível; 2 como reclamado em processo iniciado primeiro pelo México e segundo pelo EUA, relativo a suas importações nas áreas de exploração petrolífera e agrícola, respectivamente; e como terceiro de boa fé, em $16 \operatorname{casos}^{74}$. Nas negociações de Doha, participa especialmente daquelas sobre acesso a mercados de produtos não agrícolas, dentro do Programa de Doha para o Desenvolvimento ${ }^{75}$.

Isso ocorre porque o petróleo ocupa o primeiro lugar na economia e no comércio exterior venezuelanos, suas ações estão primordialmente voltadas para ele, haja vista as exportações não relacionadas ao petróleo, praticamente desaparecerem porque a indústria nacional está afetada pelas políticas oficiais. ${ }^{76}$. O produto exerce, inclusive, papel relevante na política internacional, no fortalecimento das relações multipolares com o mundo e, em particular, na política de integração latinoamericana e do caribe. Segundo o Plano Nacional Simon Bolívar, a política de plena soberania petroleira é política internacional, de aliança com todos aqueles países que insistem em se desenvolverem como nações e não aceitam ser marginalizados num mundo globalizado. $^{77}$

Para conquistar esse objetivo, o executivo pretende transformar o País em centro mundial de refinação e potência petroquímica. Outro aspecto do Plano

\footnotetext{
${ }^{73}$ AMORIM, C.L.N., Pronunciamento do Ministro Celso Amorim na VII Reunião Ministerial da OMC, em 30/11/2009.

${ }^{74}$ WTO. Disponível em: http://www.wto.org/spanish/tratop_s/tpr_s/tp207_s.htm. Acessado em: $22 / 02 / 2010$

${ }^{75}$ WTO. Observaciones formuladas por la presidenta a modo de conclusión. Disponível em: http://www.wto.org/spanish/tratop_s/tpr_s/tp207_crc_s.htm. Acesso em: 22/02/2010

${ }^{76}$ MENDONZA, M.R., entrevista ao jornal El Universal de 10/08/2009. Disponível em: http://deportes.eluniversal.com/2009/08/10/eco_art_al-mercosur-no-le-i_1513421.shtml. Acesso em: 22/02/2010.

${ }^{77}$ Plan Nacional Simon Bolívar. Ano: 2007, p. 26. Acesso: http://www.gobiernoenlinea.ve/noticiasview/shareFile/PPSN.pdf. Acesso em: 06/03/2010.
} 
Nacional Simon Bolívar é que se pratique política comercial exterior consistente com o desenvolvimento endógeno ${ }^{78}$. O comércio exterior venezuelano continua sendo, entretanto, segundo as estatísticas, mais dependente das exportações de petróleo feitas aos norte-americanos, conforme afirmativa de MENDOZA. M. R., ex-diretor geral adjunto da OMC. ${ }^{79}$

Segundo IRIARTE, E.G.V., professor venezuelano de economia internacional, em princípio, todo mercado de trocas de bem e serviço é influenciado pelos acordos gerados na OMC, mas, quando se trata de itens estratégicos importantes para um país ou grupo de países a ponto de afetar a geopolítica de uma região ou do mundo -, são indiretamente influenciados. O mercado de petróleo acolhe ou se interessa por decisões emitidas pela OMC quando são do tipo financeiro ou ambiental - se estas são em seu benefício, apóiam-nas abertamente. Na Rodada Doha, não foram discutidos temas especificamente petroleiros e mesmo que assim fosse não seriam considerados porque existem outras instancias de discussões mais fortes que a OMC, como Organização dos Países Exportadores de Petróleo (OPEP) ou o Instituto Americano de Petróleo (API). Segundo o professor, a Venezuela não está participando ativamente nos assuntos tratados em Doha nem levantou temas sobre o mercado de petróleo (informação pessoal).

Durante a Cúpula América do Sul - África (ASA), o representante da Venezuela concordou com a afirmativa de que “a conclusão da Rodada de Doha dever ser justa e equilibrada, com especial atenção nas áreas centrais da negociação, agricultura e acesso aos mercados para os produtos não agrícolas (NAMA).”. ${ }^{80}$ Para HARDY, A. T., diplomata venezuelano, a Rodada de Doha de negociações colocou o multilateralismo econômico num impasse, haja vista a confrontação entre o G20 e os países industrializados. Os EUA - do grupo dos industrializados - resolveram suas demandas pela via de tratados bilaterais, nos quais têm maior margem de exigibilidade, à diferença da que teria na negociação multilateral ${ }^{81}$.

\footnotetext{
${ }^{78}$ Idem.

${ }^{79}$ MENDONZA, M.R., entrevista ao jornal El Universal de 10/08/2009. Disponível em: http://deportes.eluniversal.com/2009/08/10/eco_art_al-mercosur-no-le-i_1513421.shtml. Acesso em: 22/02/2010.

${ }^{80}$ II Cumbre América del Sur-África (ASA). Ano: 2009.

${ }^{81}$ HARDY, A. T. Artigo: Venezuela e los tratados de libre comercio con Estados Unidos. Disponível em: http://noticias.eluniversal.com/2006/07/20/opi_art_20590D.shtml. Acesso em: 22/02/2010.
} 
Isso prejudica a Venezuela porque ela é contrária aos TLCs e à política capitalista da Casa Branca. O presidente Chávez confirmou que o seu governo enfrenta o modelo capitalista abertamente no campo das idéias. Para ele, a OMC é organização internacional imperialista e apesar disso é necessário formar parte dela. ${ }^{82}$ Com relação à Rodada de Doha, o representante permanente da República da Venezuela embaixador Germán Mundaraín disse que "a Venezuela participaria de um acordo que tivesse como norte o desenvolvimento, e que procurasse normas para negociar um comércio justo que desse um tratamento preferencial aos países com pequenas economias e aos países em vias de desenvolvimento.” ${ }^{83}$.

\subsection{Análise comparativa}

Fora o ponto de que o Brasil e a Venezuela foram membros originários da OMC, seus interesses e suas atitudes diante do órgão e nas reuniões da Rodada do Desenvolvimento são diferentes. Prima a atuação brasileira em diversos departamentos da OMC, seja nas rodadas de negociação seja no contencioso seja no Órgão de Exame das Políticas Comerciais. Com relação à Rodada Doha, o Brasil exerce papel de liderança nas negociações, enquanto a Venezuela cuida de que os acordos assinados ou a falta deles não a prejudiquem.

O agrobussines é importante para o comércio exterior brasileiro e é justamente o maior embate que impede a conclusão da Rodada Doha. O desenrolar das negociações dos demais produtos dependem da maior abertura que os países desenvolvidos deem em seu mercado. Além disso, o Brasil prefere o foro multilateral para tratar sobre assuntos de comércio exterior, mas, enquanto não se destrava a negociação por culpa dos países da União Europeia e Estados Unidos, o Brasil segue a tendência de negociar acordos regionais e bilaterais, principalmente oferecendo maiores vantagens aos países em desenvolvimento.

\footnotetext{
${ }^{82}$ Radio Nacional de Venezuela (RNV). Chávez: “EEUU es agresivo con Venezuela por no aceptar modelo neoliberal”. Disponível em:

http://64.233.163.132/search?q=cache:4WHf9XQ4fF8J:www.rnv.gov.ve/noticias/\%3Fact\%3DST\%26 f\%3D\%26t\%3D14033+Chavez+y+la+OMC\&cd=15\&hl=es\&ct=clnk\&gl=ve. Acessado em: 22/02/2010.

${ }^{83}$ APORREA.ORG, Venezuela en la OMC: hay que revisar por qué fracasan las negociaciones de Doha, de 19/12/2008. Disponível em: http://64.233.163.132/search?q=cache:I2pkVYI1sWMJ:www.aporrea.org/venezuelaexterior/n125820. html+Chavez,+OMC+y+Doha\&cd=42\&hl=es\&ct=clnk\&gl=ve. Acessado em: 22/02/2010
} 
No caso da Venezuela, o principal produto de exportação é o petróleo, o qual não está no centro da pauta de discussões. Ela forma parte do G20, porém seu principal centro de atuação está no NAMA. Miraflores considera a OMC uma organização de cunho imperialista, mas participa dela para poder ter margem de ação sobre os em assuntos que possam prejudicá-la ou favorecê-la. Estas atuações a primeira vista contraditórias fazem sentido, porque a Venezuela depende ainda muita das importações para se abastecer e a remanescente exportação que exclui o petróleo aproveita os benefícios estabelecidos nos acordos da OMC. Por sua vez, é afetada pelos TLCs praticados principalmente pelo seu principal comprador, os Estados Unidos. 


\section{A Mudança Climática: o Protocolo de Quioto e a COP - 15}

O estudo sobre a mudança climática sob os auspícios da Assembléia Geral da ONU começou quando, no início da década de 1990, foi encomendado ao Painel Intergovernamental sobre Mudança Climática (IPCC) - atualmente composto por mais de mil cientistas do mundo todo. Suas constatações têm despertado a atenção da comunidade internacional de modo alarmante e demandam ações imediatas de curto a mediano prazo sob responsabilidade de seus integrantes, a fim de evitar uma catástrofe mundial.

Algumas conclusões do IPCC foram $^{84}$ :

a) A comprovação da elevação gradual da temperatura média do Planeta.

b) A mudança da dinâmica dos sistemas naturais, como conseqüência do aumento de temperatura, que está gerando a elevação do nível do mar, a partir do derretimento das calotas polares, o que por sua vez põe em risco os interesses de países insulares e cidades à beira-mar. Igualmente, a distribuição das chuvas passará por variações, transformando áreas atualmente úmidas em secas e áreas semi-áridas em úmidas.

c) A constatação de maior presença de gases intensificadores do efeito-estufa na atmosfera - este é o ponto que explicita as divergências sobre as causas do aquecimento global.

Segundo RIBEIRO (2005, p. 125-126), há duas correntes que procuram explicar o fenômeno: aqueles que defendem que é uma ação natural, e outros que dizem ser consequência de ações antrópicas, identificadas na sociedade industrial. Atualmente, a corrente predominante é a que responsabiliza a ação humana. O desenvolvimento tecnológico adotado pela sociedade industrial caracterizou-se por gerar um crescimento acelerado do setor produtivo e que, mesmo sob forma de ciclos de expansão e desaceleração da atividade econômica, fez uso intensivo de matériasprimas fósseis para gerar energia e insumos para plantas industriais ${ }^{85}$. Acrescenta DA SILVA que, principalmente após a Segunda Guerra Mundial, o crescimento industrial intensificou os problemas ambientais ao produzir gases com propriedades

\footnotetext{
${ }^{84}$ RIBEIRO, W.C. A ordem ambiental internacional. A Conferência das Nações Unidas para o Meio Ambiente e o Desenvolvimento. 2005. p. 125. Ed. Contexto.

${ }^{85}$ DA SILVA, D.H. Artigo: Protocolos de Montreal e Kyoto: pontos em comum e diferenças fundamentais. RBPI, Ano 52, n. 2, 2009, p. 155. Ed. IBRI.
} 
físico-químicas próprias à interação com os gases da atmosfera que em conjunto afetaram a biosfera.

Antes do resultado dos estudos do IPCC, já havia surgido uma polarização entre os EUA - maior emissor de gases estufa e tinha como aliados os países exportadores de petróleo -, e a Malásia - um dos maiores detentores de florestas no mundo e apoiada por países das ilhas do Pacífico. Os EUA e seus aliados não admitiam a fixação de índices de emissão de poluentes a partir de derivados de petróleo sem que se aprofundassem mais os estudos. Ao tornar-se consenso mundial as afirmações científicas da existência dos gases poluentes e da necessidade de proteger a vida contra esses agentes nocivos, os pontos controversos agora são como reverter o problema mediante a gestão política-econômica interna dos Estados, em especial do setor energético.

Além disso, os problemas da emissão dos gases impactam a saúde pública e o meio ambiente; os governos, como responsáveis por ambos os setores, foram, igualmente, incumbidos de resolvê-los. Entretanto, como a atmosfera é universal e os efeitos causados por esses gases não estão restritos as fronteiras dos Estados, e a questão político-econômica interna - no mundo globalizado - extrapola para a política externa, tudo isso implicou na intervenção da ONU por meio da celebração de acordos internacionais que comprometeram as nações ${ }^{86}$.

Após a Conferência das Nações Unidas para o Meio Ambiente e o Desenvolvimento (CNUMAD), em 1992, ocorreram varias reuniões de negociações internacionais sobre as mudanças climáticas, das quais se destacaram neste trabalho a de Quioto (1997), que resultou no Protocolo de Quioto, e a mais recente em Copenhague $^{87}$. Na cidade japonesa, ocorreu a Quarta Conferência das Partes da Convenção de Mudanças Climáticas (CMC), uma das mais importantes rodadas da ordem ambiental internacional, num momento em que o mundo capitalista transitava por mais uma crise cíclica e a diminuição de emissão significava reduzir a atividade econômica, implicando em mais desemprego ${ }^{88}$.

\footnotetext{
${ }^{86}$ Idem, p. 156.

${ }^{87}$ RIBEIRO, W.C. A ordem ambiental internacional. A ordem ambiental internacional após a CNUMAD, p. 138. Ed. Contexto. Ano 2005

${ }^{88}$ Idem, p. 138-139.
} 
Dessa Conferência emanou o Protocolo de Quioto, que conta na atualidade com 174 países signatários - o protocolo foi ratificado por 39 países desenvolvidos, porém os EUA não ratificaram ${ }^{89}$. É um documento que visa à defesa do meio ambiente, ao procurar evitar que atividades humanas poluidoras e degradantes inviabilizem a vida sobre a Terra, por isso trata sobre o controle de emissão de gases que provocam aquecimento global. Esse controle é feito por meio de metas que limitam a poluição provocada pela queima de combustíveis fósseis - causadores do efeito estufa. Os 6 gases cujas emissões foram limitadas são metano (intensificado pelo aumento das áreas com uso intensivo de agrotóxicos e fertilizantes ${ }^{90}$ ), óxido nitroso, hidrofluorcarbono, perfluorcarbono, hexafluorsulfúrico e gás carbônico (intensificado pela queima de combustíveis fósseis $\left.{ }^{91}\right)^{92}$.

O protocolo determina redução total das emissões de 5,2\% entre 2008 e 2012 em comparação aos níveis de 1990. O documento estabelece responsabilidades diferenciadas entre os países signatários desenvolvidos e os em desenvolvimento. Somente os países industrializados, ainda que de forma variada, determinados no Anexo I do documento - um total de 42 países-, estão sujeitos a meta de emissão ${ }^{93}$. O compromisso assumido pelos países em desenvolvimento é informar à ONU do próprio nível de emissões e desenvolver estratégias para tratar as mudanças climáticas.

Existem outras 3 opções, além da redução interna das emissões: a aquisição de créditos de carbono em bolsas de ações internacionais; o investimento em projetos de redução em outra nação do Anexo I; ou a alocação de recursos em projetos de diminuição de poluentes em Estados em desenvolvimento, no âmbito do Mecanismo de Desenvolvimento Limpo (MDL). As nações, igualmente, podem obter créditos de carbono por atividades que aumentem a sua capacidade de absorvê-los, tais como plantar árvores e cuidar o solo ${ }^{94}$.

\footnotetext{
${ }^{89}$ DA SILVA, D.H. (2009) e RIBEIRO, W.C. (2005), op. cit Ref. 54 e 53; p. 160 e 140 respectivamente.

${ }^{90}$ RIBEIRO, W.C. (2005), op. cit Ref. 53; p. 12.

${ }^{91}$ Idem.

${ }^{92}$ Segundo DA SILVA (2009, p.155), o compromisso representa uma resposta internacional às conseqüências do modelo de desenvolvimento industrial adotado.

${ }^{93}$ DA SILVA, D.H. (2009) e RIBEIRO, W.C. (2005), op. cit Ref. 54 e 53; p. 160 e 140 respectivamente.

${ }^{94}$ DA SILVA, D.H. (2009), op. cit Ref. 54; p. 160.
} 
A estimação da ONU determinou que os países industrializados não atingiram as metas de redução. Somente 4 países europeus conseguirão cumpri-la e prevê o pior dos quadros para 2010, isto é, aumento de $10 \%$ em comparação a $1990^{95}$. A maior dificuldade para estabelecer o Protocolo de Quioto é de raiz econômica. Os principais poluidores - EUA e Japão - continuam emitindo mais CO2 e teriam que modificar sua estrutura econômica para alcançarem as metas. Responsável por emitir mais de um quarto do gás carbônico, os norte-americanos retiraram-se das negociações de Quioto, em 2001, sob a alegação de que sua implementação prejudicaria a economia americana $^{96}$.

A principal trava dos EUA para permanecer no Acordo foi a insistência do Congresso em alegar que é injusto o tratamento diferenciado dado aos países emergentes ${ }^{97}$. A alegação dos EUA não é de tudo absurda quando se exime de responsabilidade países como a China cuja principal fonte de energia para movimentar sua economia em expansão é a base de carvão mineral, e, não obstante, gozam dos mesmos benefícios concedidos aos países em desenvolvimento ${ }^{98}$.

Na recente reunião, na Dinamarca, no mês de dezembro de 2009, denominada COP- $15^{99}$, discutiu-se a inclusão dos países emergentes no compromisso de redução de emissões de gases poluentes. No começo das discussões, houve várias sugestões, mas, no último dia de reunião, o acordo de Copenhague propunha que países ricos reduzissem em, no mínimo, 80\% das emissões até 2050 e os países em desenvolvimento entre $15 \%$ e $30 \%$. Esse projeto teve prorrogada sua instauração para dezembro de 2010, na próxima reunião sobre clima, no México ${ }^{100}$. Países da União Européia mostraram-se abertos em assumir porcentagens maiores em comparação ao estabelecido em Quioto, em torno de 20\% a 40\%; os EUA anunciaram uma lei que está sendo votada em seu Congresso que estabelece redução em $17 \%$ até $2020^{101}$.

\footnotetext{
${ }^{95}$ Idem.

${ }^{96}$ DA SILVA, D.H. (2009), op. cit Ref. 54; p. 163.

${ }^{97}$ RIBEIRO, W.C. (2005), op. cit Ref. 53; p. 140.

${ }^{98}$ DA SILVA, D.H. (2009), op. cit Ref. 54; p. 163.

$9915^{\text {a }}$ Conferência do Clima das Nações Unidas em Copenhague.

${ }^{100}$ Folha Online. Novo projeto de acordo climático prevê meta de gases só a partir de 2010. Data: $19 / 12 / 2009$.

${ }^{101}$ Brasil Econômico. Amorim critica países ricos e cobra metas. Data: 11/12/2009.
} 
Além da diminuição da produção de gases, foi levantado o ponto do financiamento - um dos mais controvertidos. A ONU anunciou que seriam necessários 10 bilhões de dólares por ano entre 2010 e 2012, aumentado esse valor até 2020 e, no longo prazo, o custo anual global alcançaria a quantia de 300 bilhões de dólares ao ano (o dobro do previsto pelos países desenvolvidos ${ }^{102}$ ). Esse financiamento será destinado principalmente aos países em desenvolvimento para combater secas, enchentes e aumento do nível do mar provocado pelo aquecimento da Terra. Como esses efeitos já estão sendo sentidos, o financiamento é urgente e deve sofrer essa ampliação ${ }^{103}$.

A COP-15 foi considerada um fracasso por não alcançar sua finalidade, substituir o Protocolo de Quioto por meio de compromissos efetivos para conter a mudança do clima e não há boas expectativas para a COP-16 no México. Obteve-se apenas esboço de declaração política de cooperação entre as 192 nações presentes no encontro que sequer garante seu cumprimento. O texto declarava a redução de $50 \%$ das emissões e a criação do Fundo Climático Internacional que angariará 100 bilhões de dólares para financiar ações mitigadoras em países pobres e em desenvolvimento, até $2050^{104}$.

Teme-se que o único mecanismo concreto para combater o aquecimento global, o Protocolo de Quioto, esteja cada vez mais ameaçado, ainda que 25 países dentre os maiores emissores de CO2- tivessem assinado o "Acordo de Copenhague” para garantir a negociação por duas vias: o Protocolo de Quioto e outro protocolo que inclua os EUA. O alivio que restou para as ONGs presentes foi que o compromisso firmado em Bali, em 2007, continuará guiando as negociações da próxima reunião ${ }^{105}$. Hélio Gomez afirma que, apesar dos inúmeros alertas da comunidade científica, os políticos reunidos em Copenhague deixaram que os interesses econômicos prevalecessem nas discussões o que impediu melhor resultado para a cúpula sobre combate a mudança climática ${ }^{106}$.

\footnotetext{
${ }^{102}$ Agencias internacionais. Um fundo para o clima. 11/12/2009.

103 Brasil Econômico. Cúpula discute “fundo verde”. Data: 10/12/2009.

${ }^{104}$ Isto é. Eles ficaram na conversa de salão. Data: 21/12/2009.

${ }^{105}$ O Estado de São Paulo. Brasil lutará para manter Kyoto. 21/12/2009

${ }^{106}$ Isto é. Eles ficaram na conversa de salão. Data: 21/12/2009.
} 


\subsection{Brasil}

Em questões relacionadas ao meio ambiente, o Brasil tem posição única na cena internacional por possuir a maior riqueza de biodiversidade da Terra; ter variedade de ecossistemas e a maior porção da floresta Amazônica; possuir população numerosa; exibir mercado próspero e ser uma das maiores potências agrícolas. Em razão disso, é protagonista em foros internacionais desde a década de 1970, quando se trata de questões ambientais, e é também alvo de críticas relativas à conservação dos seus recursos naturais ${ }^{107}$.

Ao levar-se em consideração a dimensão das riquezas brasileiras infracitadas, é esperada sua posição determinante nesses assuntos, entretanto, em tais questões não é assim, por causa da ligação dos temas ambientais à outros assuntos de tipo econômico ${ }^{108}$. A política ambiental brasileira aproxima-se da política externa, porque o tema ambiental está presente nas agendas multilaterais ${ }^{109}$ - por aquilo que se disse na sessão anterior de que os efeitos dos problemas causados ao meio ambiente não se limitam as fronteiras. Uma das formas que a diplomacia brasileira encontrou para inserir-se mais nas questões ambientais foi oferecer o Brasil como sede da conferência sobre meio ambiente promovida pela ONU, em $1992^{110}$.

A orientação da política externa brasileira sobre questões ambientais, desde 1990, segue a linha do direito ao desenvolvimento sustentável e da defesa de princípios que o País tradicionalmente promove no campo internacional, tais como: soberania e responsabilidades comuns, porém diferenciadas. Em razão disso, afirmase que não houve grande ruptura na política externa ambiental até a atualidade. O que mudou foram as práticas diplomáticas, porque foi incluída a participação dos outros ministérios, do setor privado e da sociedade civil organizada nos debates para a construção da posição internacional do Brasil em temas ambientais ${ }^{111}$. Pode-se dizer

\footnotetext{
107 BARROS-PLATIAU, A. F. A política externa ambiental: do desenvolvimentismo ao desenvolvimento sustentável. Relações Internacionais do Brasil: Temas e Agendas. Orgs. ALTEMANI, H. e LESSA, A.C. 2006. Volume 2, Cap. 8 p. 251-281.

108 Idem, p. 252. No âmbito interno, afirma BARROS-PLATIAU (2006, p. 252) que essa transversalidade se repete, até hoje, pois não houve verdadeiro esforço político no sentido de integrar as questões ambientais às políticas de desenvolvimento. Ainda ressalta a autora que mesmo que o Brasil tenha adotado um discurso internacional e nacional fundado no desenvolvimento sustentável, as práticas domésticas comumente contradizem esse princípio e as autoridades públicas iniciam intermináveis disputas pela inexistência de políticas claras e coerentes.

${ }^{109}$ Idem, p. 259.

${ }^{110}$ Idem.

${ }^{111}$ Idem, p. 253.
} 
que o discurso da política externa para os temas ambientais consolidou-se como discurso de Estado, a linha do Governo de Luiz Inácio Lula da Silva manteve a continuidade, apesar de apresentar nuances em função do Partido dos Trabalhadores que pouco afetaram as grandes linhas e princípios da política ambiental ${ }^{112}$.

Com relação ao tema da mudança climática, há participação conjunta do Ministério das Relações Exteriores (MRE) e do Ministério da Ciência e da Tecnologia. Desde o início das negociações, a posição brasileira praticamente não foi alterada por estar sustentada nos princípios $^{113}$ da constituição para as relações internacionais; da soberania; do desenvolvimento sustentável; da cooperação nortesul; das responsabilidades comuns, porém diferenciadas; da proporcionalidade; e todos aqueles que diferenciem os países desenvolvidos dos em desenvolvimento. Em especial, o princípio das responsabilidades comuns, porém diferenciadas, vinculado ao princípio do poluidor pagador ${ }^{114}$, foi discutido com profundidade nessa questão ambiental, pois a posição brasileira consistiu em demandar dos países que primeiro se desenvolveram a sua responsabilidade histórica ${ }^{115}$. Segundo ARBIX, citado por BARROS-PLATIAU (2006, p. 270), a inclusão desses princípios foi fruto de concessões recíprocas entre os blocos do Norte e do Sul.

Para cada regime internacional sobre ambiente, o governo brasileiro angaria parcerias diferentes, encontradas no G77/China - onde atua com liderança - para construir a agenda comum. No regime de controle de mudanças climáticas, diversos grupos foram formados e reformados conforme a conversas avançavam. O Brasil encontra-se junto à China, Índia, México e Coréia do Sul, na linha de frente dos emergentes chamados a contribuir nos esforços de redução de emissões, pós-Quioto.

À época do Protocolo de Quioto, o País era um dos poucos privilegiados que se encontrava fora da linha de pressão, por ser economia emergente, possuir matriz energética relativamente limpa e ser beneficiário das propostas que incluíam cooperação. O discurso defendido pelo Brasil em Quioto foi propor mecanismos e obrigações aos países desenvolvidos, justificada na responsabilidade histórica da

\footnotetext{
${ }^{112}$ Idem, p.260.

113 BARROS-PLATIAU (2006, p. 271) destaca a sintonia da política externa brasileira com os esforços de governança ambiental global, com exceção apenas da negativa de aplicar o princípio de patrimônio comum da humanidade em questões ambientais, principalmente, porque o patrimônio exigido é a Amazônia.

${ }^{114}$ RIBEIRO, W.C. (2005), op. cit Ref. 53; p. 139.

${ }^{115}$ Idem, p. 265-270.
} 
emissão de gases provocadores de efeito estufa, e, em razão disso, deveriam arcar com o maior ônus de mitigação das emissões. Àquele tempo, o Brasil rejeitou argumentos que responsabilizassem a todos os países por igual, baseados no volume populacional. Outra iniciativa nacional foi a proposta do fundo de desenvolvimento limpo ${ }^{116}$, a qual não vingou totalmente, resultando no Mecanismo de Desenvolvimento Limpo, anteriormente comentado ${ }^{117}$.

O Brasil assumiu o compromisso da Convenção-Quadro das Nações Unidas sobre Mudança Climática de desenvolver e atualizar, de forma periódica, o inventário nacional de emissões e remoções antrópicas de gases de efeito estufa, por meio do documento denominado Comunicação Nacional. Em 2006, em ordem decrescente, os maiores contaminadores no Brasil foram: setor de transporte, em especial o rodoviário; indústria; setor energético, singularmente, o de geração de eletricidade; e o agropecuário. O $1^{\text {o }}$ inventário brasileiro foi divulgado em 2004 com informações do quadriênio 90-94 e o $2^{\circ}$ foi entregue em 2008 e informa o quinquênio 95-00. Foi detectado que o uso de terra e florestas foi responsável de 75\% das emissões, mas esses inventários, por não incluírem todas as atividades poluentes realizadas no País (como as atividades mercantes e as emissões das grandes capitais), mostram panorama incompleto da situação no Brasil ${ }^{118}$.

Com relação à contribuição brasileira no MDL, junto com a China e a Índia, o Brasil tem registrado o maior número de iniciativas - com 118 projetos aprovados, ocupa o $4^{\circ}$ lugar em número de projetos com reduções certificadas de emissões ${ }^{119}$. Segundo DA SILVA (2009, p. 162), suas iniciativas são cada vez mais inócuas no mercado de carbono, porque a matriz energética brasileira é uma das mais limpas, em relação a emissões, por estar fundada na hidroeletricidade - diferente das outras duas nações com fontes de origem fósseis, grandes responsáveis pela contaminação do ar.

O sequestro de carbono feito com a introdução de CO2 em poços de petróleo para tentar extrair o restante do óleo do subsolo e reter o gás lá é outra forma de

\footnotetext{
${ }^{116}$ Informa BARROS-PLATIAU (2006, p. 265), que "a proposta servia para incentivar os países desenvolvidos a facilitar e aumentar a transferência de recursos e de tecnologias em prol de impactos ambientais reduzidos, pois o Brasil estimou que o sucesso das políticas ambientais adotadas em nível nacional dependeria diretamente das políticas dos países mais desenvolvidos.”.

${ }^{117}$ Idem, p. 265.

${ }^{118}$ DA SILVA, D.H. (2009), op. cit Ref. 54; p. 162.

${ }^{119}$ DA SILVA, D.H. (2009), op. cit Ref. 54; p. 162.
} 
retirá-lo da atmosfera ${ }^{120}$. Nesse ponto o Brasil, sozinho, tem capacidade para armazenar o equivalente ao que o planeta emite em 80 anos, segundo KETZER, citado por DA SILVA (2009, p.166). O Centro de Pesquisa da Petrobrás (CENPES) afirma que, até 2014, se estocará aproximadamente 10 milhões de toneladas ao ano de CO2 - se essa meta for atingida este projeto representará um dos maiores em sequestro de carbono geológico, sendo 1 trilhão em reservatórios de petróleo, 10 trilhões em aqüíferos salinos e 40 bilhões em minas de carvão.

O Brasil, nas últimas conferências sobre o clima, saiu da postura defensiva para a ativa, como pode ser observado durante a COP15, na qual o Brasil atuou como representante do $G 77^{121}$ e apresentou suas propostas individuais claras para atacar o problema e assim poder demandar medidas concretas dos demais países. Dentre esses compromissos está o de cortar suas emissões em $39 \%{ }^{122}$ e de, até 2020 , reduzir o desmatamento da Amazônia em 80\%, por meio do Fundo da Amazônia ${ }^{123}$. $^{124}$

\footnotetext{
${ }^{120}$ DA SILVA, D.H. (2009), op. cit Ref. 54; p. 166.

${ }^{121}$ Brasil Econômico. Lula se prepara para reuniões da conferência. Data: 17/12/2009.

122 O Congresso Brasileiro aprovou Projeto de Lei de iniciativa do Executivo, que contém um conjunto de ações envolvendo combate ao desmatamento, agricultura, energia e siderurgia. Essas medidas deverão reduzir o crescimento das emissões brasileiras de gases de efeito estufa entre 36,1\% e 38,9\%, até 2020. Esse esforço nos custará US\$ 160 bilhões. Ou seja, US\$ 16 bilhões por ano, até 2020. Mas essa não é uma proposta para barganhar. É um compromisso que assumimos com a nação brasileira e com o mundo (Discurso do Presidente da República, Luiz Inácio Lula da Silva, na sessão plenária da Conferência das Partes da Convenção-Quadro das Nações Unidas sobre Mudança do Clima. Acesso em: 17/12/2009.
}

Disponível em:

http://www.mre.gov.br/portugues/politica_externa/discursos/discurso_detalhe3.asp?ID_DISCURSO= 3634).

Esse compromisso transformado em lei está baseado em algumas coisas que nós consideramos importantes: mudança no sistema da agricultura brasileira; mudança no sistema siderúrgico brasileiro; mudança e aprimoramento da nossa matriz energética, que já é uma das mais limpas do mundo; e assumimos o compromisso de reduzir o desmatamento da Amazônia em 80\% até 2020 (Discurso do Presidente da República, Luiz Inácio Lula da Silva, durante sessão plenária de debate informal na Conferência das Partes da Convenção das Nações Unidas sobre Mudança do Clima - COP-15. Acesso em: 18/12/2009.

Disponível em:

http://www.mre.gov.br/portugues/politica_externa/discursos/discurso_detalhe3.asp?ID_DISCURSO= 3633).

${ }^{123}$ O Funda da Amazônia destina-se a financiar programas e projetos brasileiros de redução do desmatamento.

${ }^{124}$ Afirma o presidente Lula que "só este ano conseguimos uma redução de 41,6\% no desmatamento em relação a 2008 (...). Se compararmos com a média do período 1996-2005, a queda no desmatamento este ano é de 65\%.”. Ele responsabiliza dos resultados ao Plano Amazônia, que envolve cooperação internacional e um amplo conjunto de iniciativas e investimento do governo federal e dos estados da região. (Entrevista exclusiva concedida por escrito pelo Presidente da República, Luiz Inácio Lula da Silva, aos jornais Politiken (Dinamarca) e Dagbladet (Noruega). Data: 17/12/2009. Acesso em: 18/12/2009. 
Quando o Brasil foi questionado pela exploração do petróleo do pré-sal, que aumentará as emissões de CO2, o presidente Lula defendeu que o Brasil já tinha a matriz energética mais limpa (85\% da energia elétrica e 47\% de todo o combustível utilizados são limpos e renováveis), a contribuição para a redução de emissões já é dada algum tempo; e a exploração do pré-sal, afirma ele, não alterará esse perfil energético, pois será feito de forma criteriosa e responsável. Além disso, o Presidente afirmou que não está dentro das soluções para o aquecimento global "declarar moratória a extração de petróleo”. ${ }^{125}$

O governo brasileiro acredita que o próximo documento que venha substituir o Protocolo de Quioto deve manter o seu rigor ou superá-lo, pois é uma referencia para os países desenvolvidos para estabelecer suas metas de cortes profundos e essa é a essência do conceito de compatibilidade do Plano de Ação de Bali. ${ }^{126}$ No último discurso proferido pelo Presidente do Brasil, ele afirmou que:

"se for necessário fazer um sacrifício a mais, o Brasil está disposto a colocar dinheiro também para ajudar os outros países. Estamos dispostos a participar do financiamento se nós nos colocarmos de acordo numa proposta final, aqui neste encontro [COP-15]. Agora, o que nós não estamos de acordo é que as figuras mais importantes do planeta Terra assinem qualquer documento, para dizer que nós assinamos documento (...). O Brasil não veio barganhar. As nossas metas não precisam de dinheiro externo. Nós iremos fazer com os nossos recursos, mas estamos dispostos a dar um passo a mais se a gente conseguir resolver o problema que vai

http://www.mre.gov.br/portugues/politica_externa/discursos/discurso_detalhe3.asp?ID_DISCURSO= 3631)

${ }^{125}$ Entrevista exclusiva concedida por escrito pelo Presidente da República, Luiz Inácio Lula da Silva, aos jornais Politiken (Dinamarca) e Dagbladet (Noruega). Data: 17/12/2009. Acesso:

http://www.mre.gov.br/portugues/politica_externa/discursos/discurso_detalhe3.asp?ID_DISCURSO= 3631

${ }^{126}$ Discurso do Presidente da República, Luiz Inácio Lula da Silva, na sessão plenária da Conferência das Partes da Convenção-Quadro das Nações Unidas sobre Mudança do Clima. Data: 17/12/2009. Disponível em: http://www.mre.gov.br/portugues/politica_externa/discursos/discurso_detalhe3.asp?ID_DISCURSO= 3634. Disponível em: 17/12/2009. 
atender, primeiro, a manutenção do desenvolvimento dos países em desenvolvimento."127

O Presidente considera que grande parte do financiamento para o recorte de emissões vá para a África em torno de projeto determinados - de aprofundamento das iniciativas de mitigação ou reforço da capacidade de adaptação-, para que se possa resolver tanto o problema do aquecimento da Terra quanto o desenvolvimento do continente africano. ${ }^{128}$

\subsection{Venezuela}

A biodiversidade venezuelana é uma das maiores do mundo, possui abundantes recursos hídricos praticamente intocados e zonas ambientais protegidas. Por isso o País considera-se estar entre as nações mais compromissadas com relação à Mudança Climática, pois o impacto das atividades humanas atuais põe em risco a capacidade de sobrecarga da zona centro-norte-costeira, onde a população pobre é a mais afetada pela degradação ambiental. Para os venezuelanos é importante observar o aquecimento global em razão do incremento de água que pode ocorrer em suas $\operatorname{costas}^{129}$.

Faz desse fenômeno ferramenta geradora de consciência conservacionista e espaço para a reflexão construtiva de forma a ajudar a neutralizar os seus efeitos sobre os recursos hídricos; o aumento do nível do mar; instabilidade do solo; a extinção e modificação do período de reprodução da diversidade biológica; e a desvinculação das interações ecológicas. O governo venezuelano executa ações, projetos, obras e programas que andam no compasso da ecologia, da conservação e contribuem para o cuidado da Terra. Igualmente, está em formação a Rede

\footnotetext{
${ }^{127}$ Discurso do Presidente da República, Luiz Inácio Lula da Silva, durante sessão plenária de debate informal na Conferência das Partes da Convenção das Nações Unidas sobre Mudança do Clima COP-15. Data: 18/12/2009. Disponível: http://www.mre.gov.br/portugues/politica_externa/discursos/discurso_detalhe3.asp?ID_DISCURSO= 3633. Acesso em: 18/12/2009

128 Entrevista coletiva concedida pelo Presidente da República, Luiz Inácio Lula da Silva, em conjunto com o Presidente da França, Nicolas Sarkozy. Data 17/12/2009. Disponível em: http://www.mre.gov.br/portugues/politica_externa/discursos/discurso_detalhe3.asp?ID_DISCURSO= 3637.

${ }^{129}$ Plan Nacional Simon Bolívar. Ano: 2007, p. 29. Disponível em: http://www.gobiernoenlinea.ve/noticias-view/shareFile/PPSN.pdf. Data: 06/03/2010. Acesso em: 06/03/2010.
} 
Comunitária de Conservação com a finalidade de ajudar na formação de consciência ambientalista e na capacitação dos conselhos comunais para tratar do fenômeno. ${ }^{130}$

O Estado tem ações voluntárias e caracteriza-se como país comprometido com o meio ambiente ${ }^{131}$, para tanto criou a Carteira Ambiental por meio da qual se desenvolveu sete estratégias para a conservação da diversidade biológica, contempladas na Constituição Bolivariana da Venezuela e o Plano Nacional Simon Bolívar 2007-2013. São elas: gestão da informação sobre a biodiversidade; conservação das espécies ameaçadas; conservação das áreas estratégicas para a conservação; aproveitamento sustentável da biodiversidade; prevenção, controle e erradicação de espécies estrangeiras; controle e fiscalização de organismos geneticamente modificados; e prevenção e manipulação de tráfico ou comércio ilícito de espécies. ${ }^{132}$

Além delas, o Plano Nacional Simon Bolívar, prevê incorporar energias alternativas com base em recursos renováveis; insistir na mudança do padrão produtivo em direção à tecnologias verdes; promover padrões sustentáveis de consumo; reinvestir os benefícios da exploração de recursos não-renováveis em pesquisa e desenvolvimento ${ }^{133}$.

Alguns dos projetos conservacionistas venezuelanos foram colocados em prática já há alguns anos, os quais foram apresentados na COP-15 como exemplo de contribuição do País para diminuição dos efeitos do aquecimento global, são estes: a Árvore, Missão Socialista, que é projeto de reflorestamento das bacias altas, indispensável para produção de água, manutenção de zonas florestais e sumidouro de CO2; A Substituição de Lixões a Céu Aberto por Aterros Sanitários, esta foi uma solução contemplada no Protocolo de Quioto, no anexo I, direcionada especialmente aos países desenvolvidos, que na Venezuela é conduzida com recursos próprios. ${ }^{134}$

Outras ações apresentadas também na reunião foram A Missão Revolução Energética, implementada em 2007, consiste na distribuição gratuita de lâmpadas

\footnotetext{
${ }^{130}$ Agencia Bolivariana de Noticias (ABN). Copenhague: Cumbre mundial para la reflexión y para el compromiso ambiental. Acesso em: http://www.abn.info.ve/noticia.php?articulo=210259\&lee=4. Data: 27/02/2010.

${ }^{131}$ Agencia Bolivariana de Noticias (ABN). Comisión Nacional Negociadora sobre Cambio Climático ya está en Copenhague. Acesso em: http://www.abn.info.ve/noticia.php?articulo=210345\&lee=10. Data: 27/02/2010.

${ }^{132}$ Op. cit Ref. 99.

${ }^{133}$ Idem, p.37-39.

${ }^{134}$ Op. cit Ref. 100.
} 
fluorescente em substituição de lâmpadas incandescentes - é ação nacional e pioneira com relação aos países de desenvolvidos da Comunidade Européia. O Programa $\mathrm{Ar}$ Limpo representa outro esforço, por meio do qual, aparelhos especiais medem níveis de emissão de CO2 produzido pelos ônibus nas rodoviárias do país e empresas importantes para manter a linha base da produção de gases, conforme o Protocolo de Quioto. ${ }^{135}$ A Venezuela continua apostando na produção de petróleo como seu principal elemento de economia, de desenvolvimento e estratégia geopolítica. Em relação a sua produção e uso desses recursos, alerta em seu Plano Nacional Simon Bolívar que o mesmo deve ser feito de modo a ajudar na preservação do meio ambiente, isto é, sua produção e uso deverão contribuir com a preservação e melhora do meio ambiente e da qualidade de vida das comunidades direta e indiretamente afetadas no País. A idéia é desenvolver projetos petroleiros, sobre gás e petroquímicos sustentáveis. ${ }^{136}$

A diretora de gestão e cooperação internacional do Ministério do Meio Ambiente (Minamb), Cláudia Salerno, disse que mais de $70 \%$ da energia venezuelana provém de fonte limpa, com base hidrelétrica ${ }^{137}$. Segundo o Plano Nacional Simon Bolívar, o País deverá aumentar capacidade de geração de energia hidrelétrica e promover a produção de termelétricas com base no gás natural. Do mesmo modo, ela destacou a redução de CFC e mais de 700 toneladas de substâncias que destroem a camada de ozônio que, por sua vez, também contribuem com o aquecimento global, por meio do Fundo de Reconversão Industrial ${ }^{138}$.

A Venezuela ratificou o Protocolo de Quioto assim como todos os compromissos e objetivos da Convenção de Mudança Climática. Nas questões climáticas, participam conjuntamente os ministérios do Meio Ambiente (Minamb); Energia e Petróleo (Menpet); Ciência e Tecnologia (MCTII); Finanças (MF); e Relações Exteriores (MRE). ${ }^{139}$ Ocupa o $22^{\circ}$ lugar entre os países produtores de gases de efeito estufa, o $4^{\circ}$ na América Latinha, é responsável de 0,48\% emitido, porquanto seu compromisso com o meio ambiente está garantido por ter $70 \%$ de sua energia proveniente de fontes limpas; extensa legislação ambiental; 50\% do território coberto

\footnotetext{
135 Idem.

${ }^{136}$ Op. cit Ref. 100, p. 39-43.

${ }^{137}$ Op. cit Ref. 99.

138 Op. cit Ref. 100.

139 Op. cit Ref. 99.
} 
por vegetação e a produção de petróleo voltada para a melhoria das condições sociais. ${ }^{140}$

Em razão disso, a Venezuela deu-se o luxo de recusar o MDL, na reunião de mudança climática em Nairóbi, em 2006. Alega o País que o Mecanismo contribui para manter o modelo capitalista, sem alterar os padrões de produção e consumo, por parte dos países ricos. Com o MDL, novamente, o compromisso de redução recai sobre os países pobres. O executivo venezuelano recusa as ofertas de inversões de MDLs recebidas, porque Chávez entende que os mecanismos de desenvolvimento limpo implicam em evasão, uma licença para contaminar, comprada pelos países emissores e que as medidas tomadas pela Venezuela já contribuem o suficiente. ${ }^{141}$

O posicionamento venezuelano, no âmbito internacional, em relação à mudança climática, segundo a representante do Minamb, é a mesma do G77/China a qual apóia as diretrizes do Protocolo de Quioto. Defende igualmente o argumento de que todas as nações, especialmente as desenvolvidas, devem almejar novo acordo pós-Quioto amplo e ambicioso. A Venezuela conjuntamente com a Bolívia, a Malásia e o Paraguai propõe reduções de emissões em 49\%. Com o G77 pedirá que não haja mudanças no equilíbrio de obrigações e compromissos estabelecido em Quioto, de forma que se mantenha o princípio das responsabilidades históricas. ${ }^{142}$

Cláudia Salerno afirma que não é possível reiniciar as negociações, obstando os avanços. A situação atual é produto da acumulação de gases, cuja responsabilidade é daqueles que originaram a Revolução Industrial. O aquecimento global é a acumulação de impactos históricos e, quando se fala das recentes emissões da China, Índia e Brasil, essas representam processo novo sustentado no direito ao desenvolvimento - que não está em discussão. Finalmente afirma Salerno que os países desenvolvidos devem assumir compromissos tais como aqueles assumidos voluntariamente pelos em desenvolvimento. ${ }^{143}$

\footnotetext{
${ }^{140}$ APORREA. ORG. Comunicación Popular para la Construcción del socialismo del siglo XXI. Artigo: Venezuela rechazará propuesta de países industrializados sobre cambio climático. Data de publicação: 02/11/06. Agencia Bolivariana de notícias. Disponível em: http://64.233.163.132/search?q=cache:GVy5yGoJnlAJ:www.aporrea.org/actualidad/n85977.html+M $\mathrm{DL}+\mathrm{de}+$ Venezuela\&cd $=2 \& \mathrm{hl}=\mathrm{es} \& \mathrm{ct}=\mathrm{clnk} \& \mathrm{gl}=\mathrm{ve}$

141 Idem.

142 Op. cit Ref. 99.

143 Idem.
} 
O governo venezuelano estava esperançoso de que na Cúpula de Copenhague prevalecesse o bem-estar do Planeta sobre os interesses econômicos. Apresentou-se a reunião com a disponibilidade política para avançar nas negociações e apontar os responsáveis. Defendeu que o financiamento significativo deveria partir dos países ricos a fim de gerar estratégias de adaptação à mudança climática e crescimento econômico sustentável aos países pobres. ${ }^{144}$ Mas, em razão da falta de disposição de compromisso por parte dos países ricos, o presidente venezuelano Hugo Chávez afirma que se o clima fosse um banco capitalista, já tinha sido salvo ${ }^{145}$. Com relação ao documento esboçado no último dia de reunião da COP15, o presidente disse que o "Império", na escuridão, de costas para a maioria e de maneira antidemocrática, pretendia "cozinhar” documento que ele não aceitaria nem assinaria ${ }^{146}$.

\subsection{Análise comparativa}

Com relação ao tema da mudança climática, a atitude brasileira e venezuelana é semelhante no intuito de apóio a preservação do meio ambiente e de combate à mudança climática. O tom dos discursos de Lula e Chávez é enérgico no momento de demandar ações e criticar a atuação dos principais responsáveis. As ações tomadas em prol de reverter o quadro do aquecimento global das duas nações ora destoam ora combinam.

Tanto o Brasil quanto a Venezuela - guardadas as devidas proporções possuem riquezas ambientais, cuja conservação interessa a comunidade internacional, sobre as quais defendem sua soberania para gerir os mecanismos de conservação e aproveitamento. Assinaram tanto o Protocolo de Quioto quanto a Convenção-quadro da ONU sobre o clima. Ambos advogam em conjunto ao posicionamento do G77/China - sendo o Brasil um dos porta-vozes do grupo -, que defende, dentre outros princípios importantes, o direito ao desenvolvimento, mesmo que sustentável, e responsabiliza os emissores históricos de gases de efeito estufa, os quais devem assumir maiores compromissos.

Os governos brasileiro e venezuelano promulgaram ampla legislação ambiental e os respectivos ministérios trabalham em parceria com a iniciativa

\footnotetext{
${ }^{144}$ Idem.

145 Brasil Econômico. Impasse prevalece na Cúpula do Clima. Data: 17/12/2009.

${ }^{146}$ Isto é. Eles ficaram na conversa de salão. Data: 21/12/2009.
} 
privada e a sociedade organizada em seus programas ambientais. Estes coincidem no sentido da preservação do meio ambiente, incluindo o reflorestamento de áreas, e na priorização de energias limpas - projetos apresentados pelos mandatários na COP-15. Suas ações são de cunho voluntário, haja vista que, pelo protocolo de Quioto, eles não foram obrigados a tomar medidas imediatas, apenas a apresentarem reportes periódicos.

Com relação à produção de petróleo, a Venezuela afirma que continuará sendo sua principal fonte de renda e como tal, não lhes restando mais do que garantir que procurarão fazê-lo de forma que menos degrade o ambiente. O Brasil, recentemente, encontrou enormes reservas em seu litoral, as quais também pretende explorar sob a mesma garantia venezuelana. A Petrobras, não obstante, divulgou que pretende praticar o sequestro de carbono como meio a contribuir na redução de gás carbônico no ambiente - este foi um projeto também enunciado durante a COP-15 pelos representantes brasileiros. Sobre o sequestro de carbono, não há comunicado oficial de Miraflores que expresse que este seja uma via a ser seguida pela Venezuela em seus projetos de redução de gases de efeito estufa.

Durante a Conferência do Clima em Copenhague, os mandatários apoiaram a proposta de redução de $49 \%$ das emissões, inclusive o Brasil comprometeu-se em reduzir 39\%. Exortaram, igualmente, que o financiamento do recorte das emissões fosse repassado aos países pobre em prol de seu desenvolvimento. No final da reunião, reclamaram a falta de disposição na elaboração de documento substitutivo do Protocolo de Quioto e apresentaram-se como modelos a serem seguidos pelos verdadeiros responsáveis.

Chávez argumenta que as propostas apresentadas pelos países emergentes devem ser voluntárias, pois estes têm o direito ao desenvolvimento. Entretanto, o Brasil, pelo fato de apresentar iniciativas ambiciosas, não teme mais assumir compromisso documentado. Com relação ao MDL, apesar do Brasil ter preferido um fundo de desenvolvimento limpo, não deixou de apresentar projetos, estando entre os mais participativos. O governo venezuelano, entretanto, rechaça veemente essa proposta, porque a interpreta como sendo contrária a sua orientação política e econômica. 
Do ponto de vista das consequências internas que o tema da mudança climática pode causar ao meio ambiente, a principal linha de argumentação do Planalto é de preservar sua soberania sobre o patrimônio natural brasileiro, além de procurar minimizar com políticas os impactos das já perceptíveis mudanças no ecossistema nacional. O discurso venezuelano parte das conseqüências físicas que podem ocorrer ao território venezuelano, em especial o aumento do nível do mar e as mudanças climáticas que afetam o ciclo de vida natural de suas regiões. 


\section{CONCLUSÃO}

O objetivo geral deste trabalho foi comparar as agendas externas dos Governos de Lula e Chávez para descobrir seu grau de proximidade. Como objetivo específico, procurou-se detectar, ao longo do texto, se a reforma da ONU; as ações dos EUA no combate ao terrorismo, no Afeganistão e no Iraque; a rodada de Doha da OMC; e a mudança climática, em especial, o Protocolo de Quioto e a COP-15 são ou não temas importantes nas agendas externas da Venezuela e do Brasil e se o posicionamento e atitudes perante os assuntos coincidem.

De modo geral, pode-se dizer que a reforma da ONU; a rodada Doha da OMC; e a mudança climática, em especial, o Protocolo de Quioto e a COP-15 são assuntos tratados em ambientes de negociações multilaterais. A diplomacia brasileira prefere e participa ativamente nesses foros ao contrário da Venezuela, que participa, mas não dá destaque a eles, isso se percebeu pela dificuldade em encontrar material que embasasse o posicionamento venezuelano e nas declarações emitidas. Com relação às ações dos EUA no combate ao terrorismo, no Afeganistão e no Iraque, pelas consequências desses acontecimentos, não foram ignorados por ambos os países que se pronunciaram abertamente contrários ao terrorismo e às ações militares não autorizadas pela ONU.

O posicionamento de ambos os governos, em relação à reforma da ONU, em especial do Conselho de Segurança, é compartilhado, inclusive a Venezuela apóia a candidatura do Brasil como membro permanente. Mas a atitude é diferente, pois aquela não tem interesse de formar parte do Conselho de Segurança como membro permanente e, portanto, não faz campanha para isso como o Brasil faz.

O terrorismo é rejeitado tanto pelo Planalto quanto por Miraflores. Mas a Venezuela teme, mais que o Brasil, as medidas da "Guerra Preventiva" e da “Responsabilidade de Proteger”, formuladas pelos EUA para combater o terrorismo, principalmente, porque a Venezuela é contrária ao modelo capitalista desse país e receia que este tome represália, ameaçando-a pela fronteira colombiana. A atitude tomada pelo Brasil é mais proativa no combate ao terrorismo porque promove o debate do tema em foros multilaterais, aproxima-se dos países atacados pelos Estados Unidos, propondo a paz, e porque implementa no Brasil mecanismos para minar o financiamento das células terroristas. 
A Rodada de Doha é de suma importância para agenda brasileira, pois por meio dela negocia-se a abertura do mercado agrícola - importante área comercial brasileira. Já para a economia petroleira venezuelana não é vital a conclusão da rodada, mas sim vê benefícios em que esta ocorra. Novamente a Venezuela, crítica do capitalismo norte-americano, enxerga a OMC como instituição capitalista, que se distancia do modelo econômico almejado pela nação bolivariana. Enquanto para o Brasil, esta organização é de muito proveito para angariar vantagens para seu mercado.

O tema da mudança climática é o que mais aproxima as agendas tanto nos objetivos quanto no modo de desenvolverem-se no foro. Ambos têm interesse em resguardar suas riquezas naturais, manter a exploração de petróleo, responsabilizar as nações desenvolvidas a fim de que parta desta o maior sacrifício para reverter o quadro do aquecimento global, e praticam ações voluntárias de política ambientais. Entretanto o Brasil exerce papel de porta-vos dos países em desenvolvimento e participa dos mecanismos multilaterais de Mecanismo de Desenvolvimento Limpo, do sequestro de carbono e dos créditos de carbono.

Pode-se observar que o discurso predominante do governo Chávez nesses temas foi o de contrariar a política norte-americana, preocupa-se em negar o capitalismo de Washington, desmoralizar o “império" e promover o socialismo do século XXI, mesmo que isso signifique recriminar as instâncias multilaterais por serem afetadas em suas decisões pelas posturas da nação norte-americana. O Brasil preocupasse mais em obter benefícios e prestigio para o País nesses foros e divulgar sua imagem pacifista.

As agendas globais da Venezuela e do Brasil não são parecidas, pois nesta predominam os temas multilaterais, os quais são tratados de maneira prioritária, e naquela não são prioridade. Em cada tema especificamente predominou a aproximação no resultado visado por ambos, porém diferem nas atuações, na intensidade e nas motivações particulares. 


\section{BIBLIOGRAFIA}

AMORIM, C. Discurso proferido pelo Embaixador Celso Amorim por ocasião da Transmissão do Cargo de Ministro de Estado das Relações Exteriores, em 01/01/2003. Disponível em:

http://www.mre.gov.br/portugues/politica_externa/discursos/discurso_detalhe3.asp?I D_DISCURSO=2032. Acesso em: 10/03/2010.

ARRAES, V. O Brasil e a ONU, 1999 a nossos dias: das grandes conferências às grandes pretensões. Relações Internacionais do Brasil: Temas e Agendas. Orgs. ALTEMANI, H. e LESSA, A.C. Volume 2, Cap. 1 p. 7-41, ano 2006.

BERTAZZO, J. Artigo: A nova agenda internacional de segurança põe a democracia brasileira em risco? Revista Brasileira de Política Internacional RBPI, ano 2007, p. 25-41.

BARROS-PLATIAU, A. F. A política externa ambiental: do desenvolvimentismo ao desenvolvimento sustentável. Relações Internacionais do Brasil: Temas e Agendas. Orgs. ALTEMANI, H. e LESSA, A.C. Volume 2, Cap. 8 p. 251-281, ano 2006.

CAMPOS, T.L.C. Artigo: A rodada de Doha: dificuldades e avanços nas negociações agrícolas entre países desenvolvidos e em desenvolvimento. Ano: 2008.

CARDOZO, E. La agenda de seguridad de Venezuela-Colombia en el contexto de la subregión andina e Brasil (2000-2005). Insituto Latinoamericano de Investigaciones Sociales (ILDIS). Caracas-Venezuela, ano 2006.

AMORIM, C.L.N., Pronunciamento do Ministro Celso Amorim na VII Reunião Ministerial da OMC, em 30/11/2009.

DA SILVA, D.H. Artigo: Protocolos de Montreal e Kyoto: pontos em comum e diferenças fundamentais. RBPI, Ano 52, n. 2, 2009, p. 155-172. Ed. IBRI.

HIRST, M. As cinco “AS” das relações Brasil - Estado Unidos: aliança, alinhamento, autonomia, ajustamento e afirmação. Relações Internacionais do Brasil: Temas e Agendas. Orgs. ALTEMANI, H. e LESSA, A.C. Volume 1, Cap. 4. Ano 2006, p. 91-127.

LULA DA SILVA, L. I. Discurso de posse. Ano 2003. Acessado em: http://www.mre.gov.br/portugues/politica_externa/discursos/discurso_detalhe3.asp?I D_DISCURSO=2029

MARGIOTTA, N. Artigo: Venezuela se pronuncia contra la guerra de Irak. 23/03/2003. Disponível em: http://www.mailarchive.com/latina@peacelink.it/msg01379.html. Acessado em: 14/03/2010

MELLO, V.C., Novas ameaças a paz e segurança: o papel da ONU. Reformas na ONU. Cap. 1, p. 13-28, ano 2005. 
MÉNDEZ, C.A.R. Artigo: Venezuela y la Agenda de Seguridad del Presidente Obama. Instituto Latinoamericano de Investigaciones Sociales (ildis). Ano 2009.

MESSARI, N. O Brasil e o mundo árabe. Relações Internacionais do Brasil: Temas e Agendas. Orgs. ALTEMANI, H. e LESSA, A.C. Volume 1, Cap. 8, p. 243-263, ano 2006.

PECEQUILO, C.S. A política externa dos Estados Unidos, caps. 8, 9 e 10; p. 372462. Ed. UFRGS. Ano 2005.

RÊGO, E.C.L. Artigo: Do GATT à OMC: o que mudou, como funciona e para onde caminha o sistema multilateral de comércio.

RIBEIRO, W.C. A ordem ambiental internacional. A Conferência das Nações Unidas para o Meio Ambiente e o Desenvolvimento e A ordem ambiental internacional após a CNUMAD, p. 107-143. Ed. Contexto. Ano 2005.

SATO, E., De GATT para OMC e a agenda do Brasil no comércio internacional. Relações Internacionais do Brasil: Temas e Agendas. Orgs. ALTEMANI, H. e LESSA, A.C. Volume 2, Cap. 1 p. 125-158, ano 2006.

SILVA, I.L. Discurso do Presidente da República, Luiz Inácio Lula da Silva, durante almoço em homenagem ao Primeiro-Ministro da República de Cingapura, Lee Hsien Loong, Brasília, DF, 25/11/2008, Acesso em:

SUAREZ, M.A.G. Artigo: America Latina frente aos desafios ao combate do Terrorismo internacional: Soberania versus intervenção. IPSA. Ano 2008.

VALENTE, L. e SANTORO, M. Artigo: A Diplomacia Midiática do Governo Hugo Chávez. Acesso:

http://observatorio.iuperj.br/pdfs/56_artigos_Diplomacia_Midiatica_Governo_Chave z.pdf

VALLE, V.M. A reforma do Conselho de Segurança da ONU: uma análise sobre a posição brasileira e suas repercussões. Reformas na ONU. Cap. 4, p. 95-125, ano 2005.

VALLS, L. Artigo: Histórico da Rodada Uruguai do GATT. Estudos em Comércio Exterior Vol. I, n. 3, jul/dez, ano 1997.

VIZENTINI, P. F., A política externa da Venezuela frente a globalização (19892001). P. 57-83. Venezuela: visões brasileiras. Org. GUIMARÃES, S. P. e CARDIM, C. H. Ed. IPRI. Ano 2003.

Agencias internacionais. Um fundo para o clima. Data: 11/12/2009. 
Agencia Bolivariana de Noticias (ABN). Copenhague: Cumbre mundial para la reflexión y para el compromiso ambiental. Acesso em: http://www.abn.info.ve/noticia.php?articulo=210259\&lee=4. Data: 27/02/2010.

Agencia Bolivariana de Noticias (ABN). Comisión Nacional Negociadora sobre Cambio Climático ya está en Copenhague. Acesso em: http://www.abn.info.ve/noticia.php?articulo=210345\&lee=10. Data: 27/02/2010.

APORREA. ORG, Venezuela rechazará propuesta de países industrializados sobre cambio climático,02/11/06. Disponível em:

http://64.233.163.132/search?q=cache:GVy5yGoJnlAJ:www.aporrea.org/actualidad/ n85977.html+MDL+de+Venezuela\&cd=2\&hl=es\&ct=clnk\&gl=ve.

Acessado em: 22/02/2010

APORREA.ORG, Venezuela en la OMC: hay que revisar por qué fracasan las negociaciones de Doha, de 19/12/2008. Disponível em:

http://64.233.163.132/search?q=cache:I2pkVYI1sWMJ:www.aporrea.org/venezuelae xterior/n125820.html+Chavez,+OMC+y+Doha\&cd=42\&hl=es\&ct=clnk\&gl=ve.

Acessado em: 22/02/2010

Boletín do Instituto de Altos Estudios Diplomáticos Pedro Gual. Asuntos Globales N. 8. Artigo: En búsqueda de un nuevo concepto de seguridad: la seguridad humana vs. el Consejo de Seguridad. Ano 2007. Disponível em: www.institutopedrogual.edu.ve. Acesso em: 09/03/2010.

Brasil Econômico. Cúpula discute “fundo verde”. Publicado em: 10/12/2009.

-- Amorim critica países ricos e cobra metas. Publicado em: $11 / 12 / 2009$.

.- Impasse prevalece na Cúpula do Clima. Publicado em: 17/12/2009.

Folha Online. Novo projeto de acordo climático prevê meta de gases só a partir de 2010. Publicado em: 19/12/2009.

Isto é. Eles ficaram na conversa de salão. Publicado em: 21/12/2009.

O Estado de São Paulo. Brasil lutará para manter Kyoto. Publicado em: 21/12/2009. .- OMC, em risco, admite: Doha acabou. Publicado em: 25/02/2010.

Radio Nacional de Venezuela (RNV). Chávez: "EEUU es agresivo con Venezuela por no aceptar modelo neoliberal”. Disponível em: http://64.233.163.132/search?q=cache:4WHf9XQ4fF8J:www.rnv.gov.ve/noticias/\%3 Fact\%3DST\%26f\%3D\%26t\%3D14033+Chavez+y+la+OMC\&cd=15\&hl=es\&ct=cln k\&gl=ve. Acessado em: 22/02/2010.

VOLTAIRENET.ORG. Artigo: Hugo Chávez apoya públicamente las tesis de Thierry Meyssan sobre el 11 de septiembre. Disponible em: http://www.voltairenet.org/article143442.html e o portal El Reloj.com, Chávez asegura que Bush planeó los atentados del 11-S. Publicado em: 13/09/2006. 
Disponível em: http://www.elreloj.com/article.php?id=20618 Acessados em: 14/03/2010.

WTO. Observaciones formuladas por la presidenta a modo de conclusión. Disponível em: http://www.wto.org/spanish/tratop_s/tpr_s/tp207_crc_s.htm. Acessado em: 22/02/2010. 